\title{
Asset Pricing AT THE ZERo LOWER BOUnd
}

\author{
Philip Howard
}

A dissertation submitted to the faculty of the University of North Carolina at Chapel Hill in partial fulfillment of the requirements for the degree of Doctor of Philosophy in the School of Business.

Chapel Hill

2016

Approved by:

Mariano M. Croce

Riccardo Colacito

Christian T. Lundblad

Jennifer Conrad

Anusha Chari

Robert Connolly 
(C) 2016

Philip Howard

ALL RIGHTS RESERVED 


\section{ABSTRACT \\ PHILIP HOWARD: Asset Pricing at the Zero Lower Bound. (Under the direction of Mariano M. Croce)}

In a New-Keynesian model subject to the zero lower bound (ZLB), constrained monetary policy endogenously results in time-varying equity risk premia and equity-bond market correlations. Liquidity traps at the ZLB are characterized by negatively skewed and increasingly uncertain consumption growth, labor growth, and inflation. Investors with recursive preferences price the liquidity traps, resulting in rising equity risk premiums. Real bond yields and equity returns become negatively correlated at the ZLB, while positive in normal times. The model provides a general equilibrium foundation for 1) the time-varying comovement amongst macroeconomic quantities and asset prices observed during the the Great Recession and 2) why real bonds ceased to provide investors with insurance at the ZLB, precisely when they valued it most. 


\section{ACKNOWLEDGMENTS}

I thank my advisors Riccardo Colacito, Mariano M. Croce, and Christian T. Lundblad for valuable guidance. I would also like to thank Anusha Chari, Robert Connolly, Jennifer Conrad, Anthony Diercks, and Anh Le. 


\section{TABLE OF CONTENTS}

LIST OF TABLES $\ldots \ldots \ldots \ldots \ldots \ldots \ldots \ldots \ldots \ldots \ldots$ vii

LIST OF FIGURES $\ldots \ldots \ldots \ldots \ldots \ldots \ldots \ldots \ldots \ldots$ viii

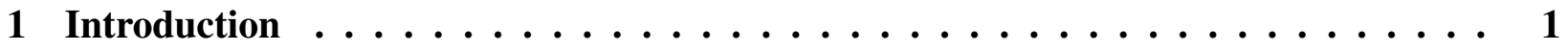

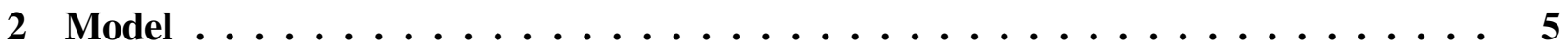

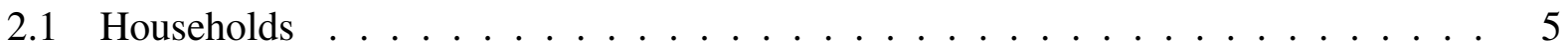

2.2 Intermediate Goods Firms . . . . . . . . . . . . . . . . 6

2.3 Final Goods Firm $\ldots \ldots \ldots \ldots \ldots \ldots$

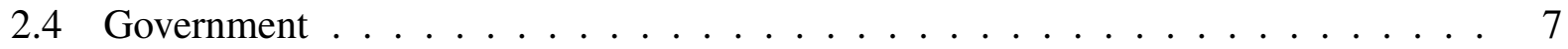

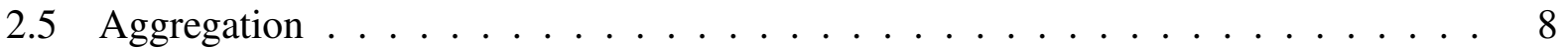

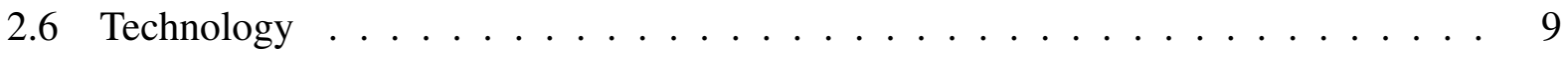

2.7 Asset Prices . . . . . . . . . . . . . . . . . . . . . . 9

2.8 Solution Method $\ldots \ldots \ldots \ldots \ldots$

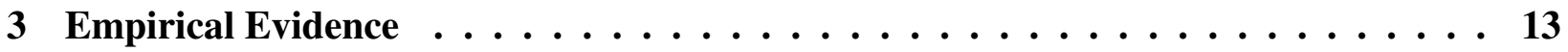

3.1 Data Sources . . . . . . . . . . . . . . . . . . . 13

3.2 Macroeconomic Quantities . . . . . . . . . . . . . . . . . . 13

3.3 Asset Prices . . . . . . . . . . . . . . . . . . . . . . . 14

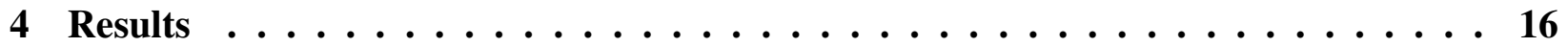

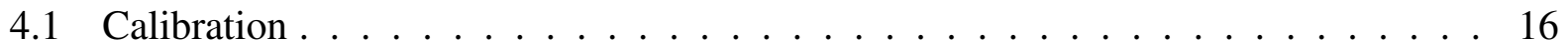

4.2 Unconditional Moments . . . . . . . . . . . . . . . . . . . . . 17 
4.3 Great Recession Dynamics . . . . . . . . . . . . . . . . . . . . . 17

4.4 Time-Varying ZLB Moments $\ldots \ldots \ldots \ldots \ldots$

4.5 ZLB Predictions . . . . . . . . . . . . . . . . . . . . . . 19

4.6 Mechanisms . . . . . . . . . . . . . . . . . . . 20

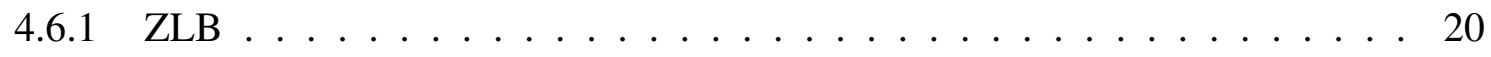

4.6 .2 EZ Preferences . . . . . . . . . . . . . . . . . . . 20

4.7 Sensitivity Analysis . . . . . . . . . . . . . . . . . 21

$4.7 .1 \quad$ No ZLB . . . . . . . . . . . . . . . . . . . . . . . 21

$4.7 .2 \quad$ CRRA: $\operatorname{IES}<1 \ldots \ldots \ldots \ldots \ldots \ldots$

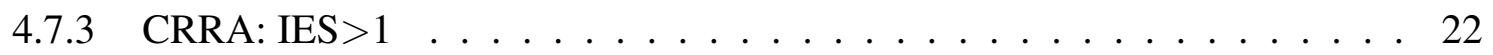

4.7.4 Long-Run Productivity and Inflation Target Correlation . . . . . . . . 22

4.7.5 GHH Preferences \& Interest Rate Smoothing . . . . . . . . . . . . 23

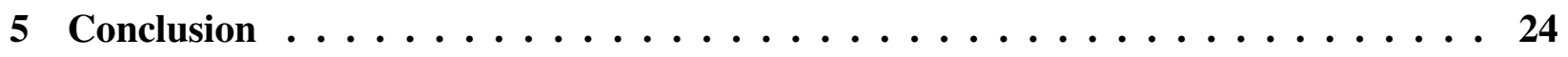

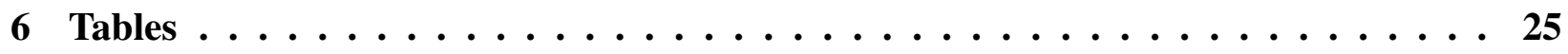

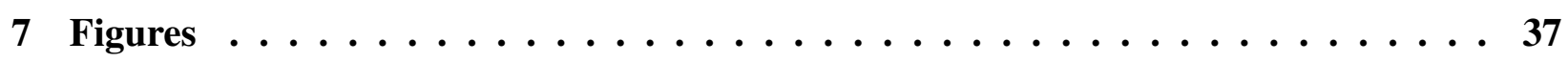

A Robustness Statistics . . . . . . . . . . . . . . . . 45

B Euler Errors $\ldots \ldots \ldots \ldots \ldots \ldots \ldots \ldots \ldots \ldots \ldots \ldots$

C Model Derivation . . . . . . . . . . . . . . . . . . . . . 49

C.1 Households . . . . . . . . . . . . . . . . . . . . . . . . . . 49

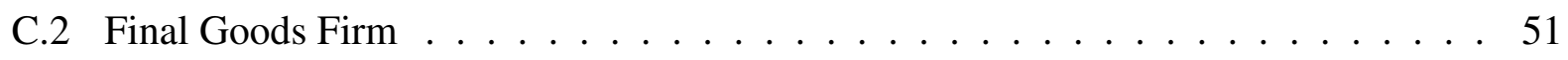

C.3 Intermediate Goods Firms . . . . . . . . . . . . . . . . . 52

C.4 Government . . . . . . . . . . . . . . . . . . . 55

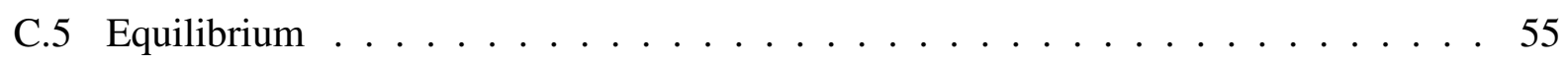

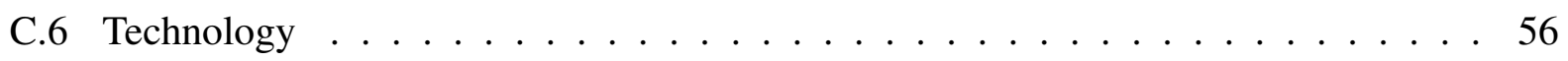

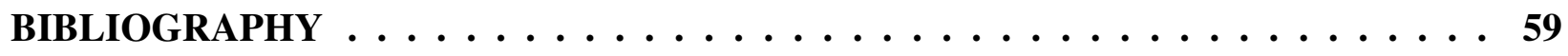




\section{LIST OF TABLES}

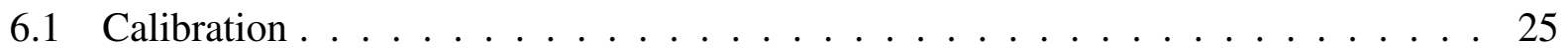

6.2 Macroeconomic Quantity Statistics . . . . . . . . . . . . . . 26

6.3 Time-Varying Macroeconomic Quantity Statistics . . . . . . . . . . . . . . 27

6.4 Yield Statistics . . . . . . . . . . . . . . . . . . . 28

6.5 Excess Return Statistics . . . . . . . . . . . . . . . . . . . . . . . . 29

6.6 Time-Varying Return Statistics . . . . . . . . . . . . . . . . . . 30

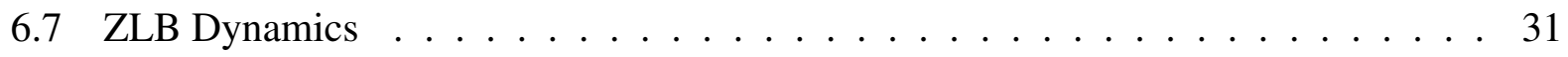

6.8 Sensitivity Analysis: Part $1 \ldots \ldots \ldots$. . . . . . . . . . . . . 32

6.9 Sensitivity Analysis: Part $2 \ldots \ldots \ldots$

6.10 Sensitivity Analysis: Part $3 \ldots \ldots \ldots$. . . . . . . . . . . . . . 34

6.11 Sensitivity Analysis: Part $4 \ldots \ldots \ldots$

6.12 Taylor Rule Estimation . . . . . . . . . . . . . . . . . . 36

A.1 Yield Statistics Implied by Inflation Swaps . . . . . . . . . . . . . . . . 45

A.2 Excess Return Statistics Implied by Inflation Swaps . . . . . . . . . . . . . 46

A.3 Time-Varying Return Statistics Implied by Inflation Swaps . . . . . . . . . . . 47 


\section{LIST OF FIGURES}

7.1 Quantities .......................... 37

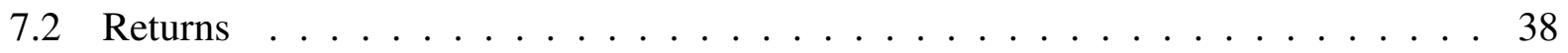

7.3 IRF: Quantities . . . . . . . . . . . . . . . . . . . . 39

7.4 IRF: Fisher Decomposition $\ldots \ldots \ldots$. . . . . . . . . . . 40

7.5 IRF: Returns . . . . . . . . . . . . . . . . . . . . . 41

7.6 IRF: Stochastic Discount Factor $\ldots \ldots \ldots \ldots$

7.7 IRF: Consumption Growth Moments . . . . . . . . . . . . . . . . . 43

7.8 IRF: Equity Risk Premium $\ldots \ldots \ldots$

B.1 Nominal Bond Euler Errors . . . . . . . . . . . . . . . . . . . . . 48 


\section{CHAPTER 1: INTRODUCTION}

Should the hedging abilities of government securities differ when monetary policy is constrained? In this paper, I answer this question by characterizing the asset pricing implications of monetary policy at the zero lower bound (ZLB). I show that a New-Keynesian model featuring investors with recursive preferences and a central bank subject to an occasionally binding ZLB constraint endogenously produces increasing equity risk premia and time-varying correlations between equity and bond markets. In equilibrium, real bonds hedge productivity declines during normal times and bear deflation risk during recessions.

The Great Recession was marked by stark comovements amongst macroeconomic quantities and asset prices. The U.S. saw large declines in productivity growth, consumption growth, labor, and inflation. Consumption growth became increasingly uncertain. The Federal Reserve's traditional policy tool became restricted by the effective ZLB at the recession's trough. In the run-up to the ZLB, nominal and real yields fell. At the ZLB, breakeven inflation yields sharply declined while real yields rose. At the same time, equity prices were declining. The negative equity-real bond correlation at the ZLB contrasts with the empirical observation that equity returns are positively correlated with real bond yields on average.

I show that a New-Keynesian model subject to the ZLB is empirically consistent with the dynamics during the Great Recession and provides a general equilibrium foundation for the observed time-varying comovement amongst macroeconomic quantities and asset prices during times of constrained monetary policy. More broadly, empirical observations of the ZLB are infrequent in the data, which makes measuring time-varying risk premia difficult. The model provides theoretical insight into the dynamics of risk premia during these extreme times.

In the model, intertemporal allocations depend on two channels: a wage channel and a savings channel. The central bank sets the price of nominal bonds according to a Taylor rule subject to 
the ZLB. Monopolistic competitive firms choose labor and prices to maximize profits. Inflation endogenously results as the discounted sum of firms' future marginal costs. Households optimally choose consumption, labor supply, and nominal bond holdings. In response to a negative longrun supply news shock, wages fall and households supply less labor. To counteract this via the savings channel, the central bank lowers the nominal interest rate, which decreases households' incentive to save, stimulates aggregate demand, and increases demand for labor. On net, the wage channel dominates and labor declines. Declining labor implies declining marginal costs and falling inflation.

At the ZLB, monetary policy becomes constrained and cannot further stimulate the economy, resulting in a liquidity trap à la Krugman (1998). Households foresee falling future prices and delay current consumption, decreasing current aggregate demand and further decreasing demand for labor. Thus in normal times, the savings channel counteracts the wage channel, while at the ZLB, the savings channel amplifies the effects of the wage channel. The liquidity trap at the ZLB results in larger declines in consumption, labor, and inflation with respect to negative long-run productivity news relative to normal times. Hence, the ZLB is characterized by negatively skewed and increasingly uncertain macrofundamentals.

With respect to asset prices, liquidity traps at the ZLB result in an increasing equity risk premium and time-varying equity-bond market correlations. In the model, equity is measured as a levered consumption claim. The ZLB results in negatively skewed and increasingly uncertain equity returns. In response to the increased downside risk at the ZLB, risk averse investors demand a higher equity risk premium.

Consistent with the data, real yields hedge productivity risk in normal times. In response to negative long-run productivity news, real bond prices rise. In contrast at the ZLB, negative longrun productivity news decreases expected inflation persistently. Given the constraint of the ZLB, real yields rise to offset falling expected inflation. Hence real bonds bear deflation risk at the ZLB.

Noting the implications for the time-varying comovement of equity and bond markets, the model implies equity returns and real bond yields are positively correlated in normal times and 
become negatively correlated at the ZLB. This is consistent with the time-varying correlation observed during the Great Recession. In normal times investors can hedge falling equity prices by selling real bond holdings. However, in times of extremely poor growth prospects when monetary policy becomes constrained, real bond prices also fall and no longer provide insurance to investors. Consequently, investors are unable to obtain portfolio insurance from real bonds at precisely the time they value it the most. A normative asset pricing implication of the model is that holding a combination of both real and nominal bonds is optimal in a diversified portfolio. Real bonds hedge declines in equity prices during normal times, while nominal bonds' inflation exposure hedges declines in equity prices during recessions.

This paper contributes to overlapping active areas of the macroeconomic and asset pricing literatures that seek to better understand jointly quantity and price dynamics. In the asset pricing literature, Bansal and Yaron (2004) and Croce (2014) show the importance of recursive preferences and long-run risk in reconciling key asset pricing moments including a low risk-free rate and a large equity risk premium, while Piazzesi and Schneider (2007) and Bansal and Shaliastovich (2013) study the term structure implications in models with exogenous inflation dynamics, reconciling an upward sloping nominal term structure and bond return predictability. In a reduced form setup, Campbell, Sunderam, and Viceira (2013) study the time-varying comovement of equity and bond returns.

To better understand the connection between asset pricing and macroeconomics, Rudebusch and Wu (2008), Bekaert, Cho, and Moreno (2010), Swanson and Rudebusch (2012), Li and Palomino (2014), Kung (2015), and Campbell, Pflueger, and Viceira (2015) endogenize inflation with price rigidities via the New-Keynesian frameworks of Clarida, Galí, and Gertler (1999) and Schmitt-Grohé and Uribe (2007). These studies find that nominal rigidities and monetary policy play key roles in understanding the properties of the term structure.

Concurrently, economists have explored the empirical and theoretical implications of the ZLB. Kim and Singleton (2012) compare the performance of various term-structure models with a ZLB to observed Japanese yields, showing shadow rate models in the spirit of Black (1995) perform 
well. Swanson and Williams (2014) argue that medium- and longer-term interest rates during the Great Recession imply the ZLB was not a large constraint on monetary policy. Campbell, Shiller, and Viceira (2009) and Pflueger and Viceira (2016) study the dynamics of the bond markets during the Great Recession, showing liquidity was an important bond factor during these times.

In general equilibrium models, Adam and Billi (2006), Basu and Bundick (2015), Nakata (2012), and Fernández-Villaverde, Gordon, Guerrón-Quintana, and Rubio-Ramírez (2015) analyze the nonlinear macroeconomic consequences of the liquidity trap. These theoretical papers show that liquidity traps are characterized by greater declines in consumption, inflation, and labor and increases in uncertainty. As is traditional in the macroeconomic ZLB literature, these papers use exogenous demand shocks (i.e., shocks to the subjective discount factor) to reach the ZLB.

This paper makes an important methodological contribution to the ZLB literature by introducing long-run supply shocks (i.e., small but highly persistent long-run productivity news shocks) as a mechanism of reaching the ZLB. In the model, negative long-run supply shocks result in falling wages and declining labor. Declining productivity and labor implies declining consumption growth and falling real yields. In addition, declining labor reduces firms' marginal costs, which result in falling inflation. Via the Fisher relationship, falling real rates and inflation thus results in falling nominal rates. As presented next, these dynamics are empirically consistent with data during the Great Recession. More broadly, this paper contributes to the New-Keynesian macroeconomic and long-run risk asset pricing literatures by studying the ZLB implications for bond and equity markets. The general equilibrium model allows theoretical insights into the mechanisms driving the asset pricing dynamics during the crisis, including the comovement of equity prices and real yields.

Next I discuss the theoretical model and then the empirical evidence of quantities and prices during the Great Recession in section 3. The model's results are presented in section 4. Section 5 concludes. 


\section{CHAPTER 2: MODEL}

\section{Households}

Households choose consumption $C_{t}$, leisure $L_{t}$, labor $N_{t}$, and nominal discount bond holdings $B_{t}$ to maximize lifetime utility $U_{t}$ given by Epstein and Zin (1989) (EZ) recursive preferences

$$
\begin{aligned}
U_{t} & =\left[(1-\beta) \tilde{C}_{t}^{1-\frac{1}{\psi}}+\beta E_{t}\left[U_{t+1}^{1-\gamma}\right]^{1-\frac{1}{\psi}}\right]^{\frac{1}{1-\frac{1}{\psi}}} \\
\tilde{C}_{t} & =C_{t}^{\varphi}\left(A_{t} L_{t}\right)^{1-\varphi} \\
1 & =N_{t}+L_{t}
\end{aligned}
$$

where $\tilde{C}_{t}$ is the consumption-leisure bundle, $A_{t}$ is labor-augmenting productivity, and the time endowment is normalized to $1 . \psi$ and $\gamma$ are the intertemporal elasticity of substitution and risk aversion. When $\gamma=\frac{1}{\psi}$, EZ recursive preferences collapse to time-separable CRRA preferences.

The household's budget constraint is

$$
P_{t} C_{t}+\frac{B_{t+1}}{I_{t}^{f}} \leq B_{t}+W_{t} N_{t}
$$

where $P_{t}$ is the price of consumption $C_{t}, I_{t}^{f}$ is the nominal interest rate, and $W_{t}$ is the nominal wage rate. The real stochastic discount factor (SDF) $M_{t+1}$ is

$$
M_{t+1}=\beta \Delta C_{t+1}^{-\frac{1}{\psi}}\left(\frac{U_{t+1}}{E_{t}\left[U_{t+1}^{1-\gamma}\right]^{\frac{1}{1-\gamma}}}\right)^{\frac{1}{\psi}-\gamma}
$$


and the real and nominal bond Euler equations are

$$
\begin{aligned}
& 1=E_{t}\left[M_{t+1} R_{t}^{f}\right] \\
& 1=E_{t}\left[M_{t+1} \frac{I_{t}^{f}}{\Pi_{t+1}}\right]
\end{aligned}
$$

where $R_{t}^{f}$ is the real risk-free interest rate and inflation $\Pi_{t+1}=\frac{P_{t+1}}{P_{t}}$. Labor supply is determined by

$$
\frac{W_{t}}{P_{t}}=\frac{1-\varphi}{\varphi}\left(\frac{C_{t}}{L_{t}}\right)
$$

\section{Intermediate Goods Firms}

Monopolistically competitive firms maximize discounted future real profits by choosing labor demand $N_{i t}$ and prices $P_{i t}$ to produce $Y_{i t}$. Firms have constant returns to scale production technologies

$$
Y_{i t}=A_{t} N_{i t}
$$

Firms' labor demand leads to the intratemporal condition

$$
W_{t}=M C_{i t} \cdot M P N_{i t}
$$

where $M C_{i t}$ and $M P N_{i t}$ are the firms' marginal costs and marginal product of labor. Prices are assumed to be sticky à la Calvo (1983). Each period, firms can update their price $P_{i t}$ with probability $1-\theta$. Maximizing discounted future real profits, firms choose price $P_{i t}$ as

$$
\frac{P_{i t}}{P_{t}}=\frac{\eta}{\eta-1} \frac{E_{t}\left[\sum_{j=0}^{\infty} \theta^{j} M_{t, t+j} \Pi_{t+j}^{\eta} Y_{t+j} m c_{i, t+j}\right]}{E_{t}\left[\sum_{j=0}^{\infty} \theta^{j} M_{t, t+j} \Pi_{t+j}^{\eta-1} Y_{t+j}\right]}
$$


where $M_{t, t+j}=\prod_{k=1}^{j} M_{t+k}$ is the SDF from time $t$ to $t+j$ and $m c_{i t}=\frac{M C_{i t}}{P_{t}}$ are real marginal costs. Firms choose their price as a markup $\frac{\eta}{\eta-1}>1$ over discounted marginal costs.

\section{Final Goods Firm}

A final goods firm buys a continuum of intermediate goods $Y_{i t}$ at prices $P_{i t}$ and produces the aggregate good $Y_{t}$ with CES technology

$$
Y_{t}=\left[\int_{0}^{1} Y_{i t}^{1-\frac{1}{\eta}} d i\right]^{\frac{1}{1-\frac{1}{\eta}}}
$$

where $\eta$ is the elasticity of substitution across different varieties of goods. $Y_{i t}$ are chosen to minimize total expenditure. At the optimum

$$
Y_{i t}=\left(\frac{P_{i t}}{P_{t}}\right)^{-\eta} Y_{t}
$$

and the aggregate price index $P_{t}$ is

$$
P_{t}=\left[\int_{0}^{1} P_{i t}^{1-\eta} d i\right]^{\frac{1}{1-\eta}}
$$

\section{Government}

Monetary policy follows a Taylor (1993) rule

$$
\frac{I_{t}^{* f}}{I}=\left(\frac{I_{t-1}^{* f}}{I}\right)^{\rho_{I}}\left[\left(\frac{Y_{t}}{\bar{Y}_{t}}\right)^{\beta_{Y}}\left(\frac{\Pi_{t}}{\Pi}\right)^{\beta_{\pi}}\left(\frac{P_{t}}{\bar{P}_{t}}\right)^{\beta_{P}}\right]^{1-\rho_{I}} e^{\varepsilon_{i, t}}
$$

subject to the zero lower bound

$$
I_{t}^{f}=\max \left(1, I_{t}^{* f}\right)
$$

where $\varepsilon_{i, t}$ is a monetary policy shock and $\rho_{I}, \beta_{Y}, \beta_{\pi}$, and $\beta_{P}$ represents the degree to which the central bank smooths interest rates and targets the output gap, inflation gap, and price level gap. 
$\bar{Y}_{t}=Y_{0} e^{\mu t}$ follows a deterministic trend for output and the price level gap follows

$$
\begin{aligned}
\frac{P_{t}}{\bar{P}_{t}} & =\frac{\Pi_{t}}{\bar{\Pi}_{t}} \frac{P_{t-1}}{\bar{P}_{t-1}} \\
\bar{\Pi}_{t} & =\prod e^{x_{\pi, t}} \\
x_{\pi, t} & =\rho_{\pi} x_{\pi, t-1}+\varepsilon_{\pi, t}
\end{aligned}
$$

where $\varepsilon_{\pi, t}$ is an inflation target shock.

The price level gap response can be thought of as a reduced form setup of unconventional monetary policy. In a standard Taylor rule, the central bank responds to the inflation gap, i.e., shocks to price level growth rates. However, at the ZLB, the central bank is constrained and can no longer respond to deviations in the inflation gap. With price level targeting, the central bank is able to credibly communicate that they will lower future policy rates to combat current price level deviations. Credibly committing to lower future policy rates acts as stimulus today, and prevents labor and inflation from falling as severely relative to a Taylor rule without price level targeting.

\section{Aggregation}

A symmetric equilibrium is imposed. The aggregate resource constraint is

$$
Y_{t}=C_{t}
$$

Aggregate output is given by

$$
\begin{aligned}
Y_{t} & =\frac{A_{t} N_{t}}{S_{t}} \\
S_{t} & =(1-\theta)\left(\frac{P_{i t}}{P_{t}}\right)^{-\eta}+\theta \Pi_{t}^{\eta} S_{t-1}
\end{aligned}
$$


where price dispersion $S_{t} \geq 1$ represents output loss due to the inefficiency of firms charging different prices. Finally, prices follow

$$
P_{t}^{1-\eta}=(1-\theta) P_{i t}^{1-\eta}+\theta P_{t-1}^{1-\eta}
$$

\section{Technology}

Productivity growth follows a deterministic trend $\mu$ and is exposed to short and long-run risk, where long-run risk $x_{t}$ is a small but highly persistent process.

$$
\begin{aligned}
\ln \Delta A_{t+1} & =\mu+x_{t}+\varepsilon_{a, t+1} \\
x_{t+1} & =\rho_{x} x_{t}+\varepsilon_{x, t+1}
\end{aligned}
$$

$\varepsilon_{a, t}, \varepsilon_{x, t}, \varepsilon_{i, t}$, and $\varepsilon_{\pi, t}$ are Gaussian random variables. All shocks except $\varepsilon_{x, t}$ and $\varepsilon_{\pi, t}$ are assumed to be mutually independent.

\section{Asset Prices}

Denoting time units in quarters, define the one quarter excess bond holding period returns as

$$
\begin{aligned}
& \operatorname{exr}_{t, n}^{\$}=i_{t, n}-i_{t+1, n-1}-i_{t, 1} \\
& \operatorname{exr}_{t, n}^{r}=r_{t, n}-r_{t+1, n-1}-r_{t, 1} \\
& \operatorname{exr}_{t, n}^{\pi}=b_{t, n}-b_{t+1, n-1}-b_{t, 1}
\end{aligned}
$$

where $i_{t, n}$ and $r_{t, n}$ are the $\log$ nominal and real interest rates from time $t$ to $t+n$ and defining breakeven inflation $b_{t, n}=i_{t, n}-r_{t, n}$ as the difference between nominal and real rates. exr $r_{t, n}^{\$}$ represents the excess return over the short-term nominal risk-free rate of buying an $n$ period nominal bond at time $t$ and selling it as an $n-1$ period bond at time $t+1 . \operatorname{exr}_{t, n}^{r}$ and $e x r_{t, n}^{\pi}$ are analogous to $\operatorname{exr}_{t, n}^{\$}$, defined over real bonds and breakeven inflation. Returns of 3 year bonds over a quarterly holding period are computed empirically. 
The market return $R_{t}^{M}$ is defined as the return to a claim on the consumption stream

$$
\begin{aligned}
1 & =E_{t}\left[M_{t+1} R_{t+1}^{M}\right] \\
R_{t+1}^{M} & =\frac{P_{t+1}^{C}+C_{t+1}}{P_{t}^{C}}
\end{aligned}
$$

Denote the log market return as $r_{t, n}^{M}$ from time $t$ to $t+n$ and define the excess equity return as

$$
\operatorname{exr}_{t, n}^{M}=r_{t, n}^{M}-r_{t, n}
$$

Note that the real rate is known at time $t$ while the equity return is realized at time $t+n$. Risk premiums are conditional expectations of excess returns. For illustration purposes, assuming the $\mathrm{SDF}$ and inflation are jointly log-normal, the risk premiums of the expected returns defined in the empirical section are

$$
\begin{aligned}
E_{t}\left[\operatorname{exr}_{t, n}^{M}\right] & =-\operatorname{Cov}_{t}\left(m_{t, 1}, r_{t, n}^{M}\right) \\
E_{t}\left[\operatorname{exr}_{t, j, n}^{\$}\right] & =E_{t}\left[\operatorname{exr}_{t, j, n}^{r}\right]+E_{t}\left[\operatorname{exr}_{t, j, n}^{\pi}\right] \\
E_{t}\left[\operatorname{exr}_{t, j, n}^{r}\right] & =\operatorname{Cov}_{t}\left(m_{t, 1}, r_{t+j, n-j}\right) \\
E_{t}\left[\operatorname{exr}_{t, j, n}^{\pi}\right] & =\operatorname{Cov}_{t}\left(m_{t, 1}, \pi_{t+j, n-j}\right)+\operatorname{Cov}_{t}\left(\pi_{t, 1}, m_{t+j, n-j}\right)+\kappa_{\pi, t}
\end{aligned}
$$

where $m_{t, j}=\sum_{k=1}^{j} \ln M_{t+k}$ and $\pi_{t, j}=\sum_{k=1}^{j} \ln \Pi_{t+k}$ are the $j$ period log SDF and inflation rates. The equity risk premium is determined by the negative covariance of market return with the SDF. Equities that have low returns in bad economic times will command a positive risk premium.

The nominal bond risk premium can be decomposed into the real bond risk premium and the breakeven inflation risk premium. The real bond risk premium is determined by the positive covariance between the SDF and future real rates. Real bonds are hedges and command a negative risk premium if future real bond prices rise in bad economic times. The breakeven inflation risk premium is a function of the positive covariance between short-run SDF and inflation with future long-run inflation and SDF. Breakeven inflation exposures are risky and command a positive risk 
premium if inflation rises during bad economic times, resulting in lower real returns on nominal bonds.

\section{Solution Method}

Denote the stationary variable $V_{t} \equiv\left(\frac{U_{t}}{A_{t}}\right)^{1-\frac{1}{\psi}}$. An equilibrium is defined as $\left\{V_{t}, N_{t}, \zeta_{t}, \xi_{t}\right\}$ that satisfies the Bellman equation, nominal bond Euler equation, and firms' price setting first order conditions

$$
\begin{aligned}
V_{t} & =(1-\beta)\left(\frac{\tilde{C}_{t}}{A_{t}}\right)^{1-\frac{1}{\psi}}+\beta E_{t}\left[\Delta A_{t+1}^{1-\gamma} V_{t+1}^{\frac{1-\gamma}{1-\frac{1}{\psi}}}\right]^{\frac{1-\frac{1}{\psi}}{1-\gamma}} \\
1 & =E_{t}\left[M_{t+1} \frac{I_{t}^{f}}{\Pi_{t+1}}\right] \\
\zeta_{t} & =M C_{t} \cdot \frac{Y_{t}}{A_{t}}+\theta E_{t}\left[M_{t+1} \Pi_{t+1}^{\eta} \zeta_{t+1} \Delta A_{t+1}\right] \\
\xi_{t} & =\frac{Y_{t}}{A_{t}}+\theta E_{t}\left[M_{t+1} \Pi_{t+1}^{\eta-1} \xi_{t+1} \Delta A_{t+1}\right]
\end{aligned}
$$

subject to the intratemporal constraints (see Appendix $\mathrm{C}$ for complete specification). The time $t$ value and policy functions are functions of four endogenous and three exogenous state variables. The endogenous state variables are the lagged nominal interest rate $I_{t-1}^{f}$, the lagged output gap $\frac{Y_{t-1}}{\bar{Y}_{t-1}}$, the lagged price level gap $\frac{P_{t-1}}{P_{t-1}}$, and lagged price dispersion $S_{t-1}$. The exogenous state variables are long-run productivity risk $x_{t}$, monetary policy shock $\varepsilon_{i, t}$, and cumulative inflation target shock $x_{\pi, t}$.

To accurately capture the effects of the occasionally binding ZLB, the non-linear model is solved with the global solution method time iteration of Coleman (1990). Given today's value and policy functions, expectations in the intertemporal Bellman equation, nominal bond Euler equation, and firms' price setting FOCs are computed for time $t+1$ variables. Using Newton's method with a symbolic Jacobian, time $t$ value and policy functions are updated. The iterations are stopped when the maximum change in any updated value or policy function is less than $1 \cdot e^{-8}$. Piecewise linear splines are used for function approximations because they are shape preserving and have smaller Euler errors around the ZLB than cubic splines or Chebyshev polynomials. Numerical 
integration is performed using Gauss-Hermite quadrature. Grid bounds for the endogenous state variables are chosen such that they contain \pm 3 standard deviations from the stochastic steady state when simulated for 12,000 periods (i.e. 1,000 years).

To check the accuracy of the approximation, Euler errors for the nominal interest rate are plotted in Figure B.1. The average and maximum relative error are $0.1 \%$ and $1.3 \%$ of the nominal interest rate's stochastic steady state, which correspond to annualized pricing errors of 0.6 bps and 8 bps respectively. 


\section{CHAPTER 3: EMPIRICAL EVIDENCE}

\section{Data Sources}

Productivity growth is from Fernald (2014). Real consumption and wages are from the Bureau of Economic Analysis (BEA). Consumption is defined as non-durable expenditures plus services. Wages are defined as wages and salaries. Both series are deflated by their corresponding price indices. The wage rate is defined as wages divided by hours worked. Hours worked are from Valerie Ramey's website. Consistent with Ohanian and Raffo (2012)'s construction, hours worked are normalized by total hours, where total hours per year is defined as civilian noninstitutional population over 16 multiplied by 14 working hours per day $\times 365$ days per year. The population series is from the Bureau of Labor Statistics (BLS). Inflation is measured using the consumer price index for all urban consumers (CPI) from the BLS. All macroeconomic data is measured quarterly. Forecasts of real total consumption expenditure are from the Survey of Professional Forecasters $(\mathrm{SPF})$.

The 3 month effective federal funds rate is from the Federal Reserve's Economic Database (FRED). Inflation swaps are from Datastream. Nominal bond yields are from the Center for Research in Security Prices (CRSP) Risk Free Rate and Fama-Bliss discount bond files. Real bond yields are from the Federal Reserve's FAME database, who estimate zero-coupon, carry adjusted yield curves using on- and off-the-run Treasury Inflation Protected Securities (TIPS). The 3 month real interest rate is interpolated from the yield curve using a cubic spline. The market return is the value weighted return of all firms from the NYSE, AMEX, and NASDAQ from CRSP. Real market returns are constructed by deflating the market price index and dividends by the CPI.

\section{Macroeconomic Quantities}

The Great Recession saw large movements of both macroeconomic quantities and asset prices. As shown in Figure 7.1, by 2007 productivity growth was declining and continued falling through 
2009. Using predictive regressions, expected productivity is estimated by regressing productivity growth onto lagged consumption growth and lagged price-dividend ratio

$$
\Delta a_{t+1}=\beta_{0}+\beta_{1} \Delta c_{t}+\beta_{2} p d_{t}+\varepsilon_{t+1}
$$

Expected productivity growth during this time period was also declining. In an effort to stimulate the economy, the Federal Reserve began lowering the Federal Funds rate in September of 2007 and continued lowering the rate until they effectively became constrained by the ZLB in December 2008. The policy rate remained between $0 \%$ to $0.25 \%$ through 2015 .

Simultaneously during the recession, consumption growth, hours worked and inflation fell sharply. Over the course of the recession from 2007Q4 to 2009Q2, cumulative quarterly consumption growth was $-1.24 \%$ and hours worked fell by $7.66 \%$. At the recession's trough when the Federal Reserve hit the ZLB, inflation fell so dramatically that it culminated in deflation over 2008Q4 to 2009Q1 with an annualized rate of $-6.6 \%$. Uncertainty, as proxied for using volatility of analysts' forecasts, for consumption growth also spiked during this period.

\section{Asset Prices}

During the recession, stock prices fell $-53 \%$, as shown in Figure 7.2. From the start of the recession in 2007Q4 to the 2008Q3, the 3-month nominal and real bond yields fell $-3.46 \%$ and $-2.57 \%$. At the ZLB over 2008Q4 to 2009Q1, the 3 year nominal bond yield fell, with short-term

yields falling faster, causing a positive and increasing nominal spread. Real bond yields rose, with short-term yields rising faster, implying a negative real spread increasing in magnitude. Breakeven inflation, defined as the difference between nominal and real rates, fell and became negative. Shortterm breakeven inflation yields fell faster, causing a positive and increasing inflation spread.

Examining correlations between equity and real bond markets, the correlations between equity returns and real yields is 0.44 over 2004 to 2008Q3, while the correlation became negative at the ZLB over 2008Q4 to 2014 with a coefficient of -0.54. For robustness, Table A.1 and Table A.2 replicate the results for real yields and breakeven inflation using inflation swaps instead of TIPS. 
In addition to matching the dynamics observed during the Great Recession, the model also matches unconditional equity and bond market moments. Examining correlations between equity and bond markets, nominal and inflation excess returns are positively correlated with equity excess returns while real and equity excess returns are negatively correlated unconditionally. Using a long sample from the U.K., Bansal, Kiku, and Yaron (2012) show the real yield curve is downward sloping. Although real bonds have only been actively trading since 2004 in the U.S, the average quarterly yield spread between 3 year and 3 month real yields prior to the Great Recession is $0.14 \%$. A downward sloping real curve implies that real bonds provide investors insurance by hedging declines in productivity and equity prices.

The empirical evidence during the Great Recession suggests the relationship between equity and real bonds are structurally different at the ZLB. Furthermore, it implies real bonds cease to provide investors portfolio insurance during extreme downturns, precisely when they value it most. The theoretical source of this time variation is investigated in the next sections.

While understanding the implications of constrained monetary policy is important, empirically it is difficult to measure due to the highly conditional nature of the ZLB and its infrequent observations. In addition, real bonds in the U.S. have only been trading actively since 2004. Since measuring the potentially time-varying equity and bond market correlations at the ZLB is empirically challenging, it is important to appeal to general equilibrium models to help interpret the data observed during the Great Recession and understand mechanisms at play.

In summary, the empirical dynamics for any general equilibrium model of the ZLB is clear. On the macroeconomic side, the model must reach the ZLB via large drops in expected productivity growth, consumption growth, and hours worked. With respect to prices, the path to the ZLB was marked by falling equity prices, nominal yields, and real yields. Finally, the ZLB was marked by large deflation, rising real yields, and equity returns that are negatively correlated with real yields. 


\section{CHAPTER 4: RESULTS}

\section{Calibration}

The model is calibrated to match 1) the unconditional quantity and asset pricing moments in the post-Bretton Woods era, 2) the empirical dynamics observed during the Great Recession, and 3) the conditional quantity and asset pricing moments at the ZLB. Over the 45 year span from 1971 to 2015, the Federal Reserve was at the effective ZLB (defined as less than $0.25 \% 3$ month nominal yield) for 7 years from 2009 to 2015, or $15.6 \%$ of the sample. The benchmark calibration hits the effective ZLB $12.5 \%$ when simulated for a long sample.

The model is solved at a monthly frequency and annualized parameter values are reported. For the benchmark calibration, mean productivity growth is calibrated to match the unconditional consumption growth rate of $2.75 \%$. Consistent with the long-run risk literature of Bansal and Yaron (2004) and Croce (2014), the intertemporal elasticity of substitution is 2, risk aversion is 10 , and expected productivity growth shocks have an annual persistence of 0.85 . The subjective discount factor is set to 0.985 and steady state labor hours is chosen to match the data in which $22 \%$ of total hours is devoted to working.

Consistent with the Taylor rule estimation in Table 6.12, the central bank places a weight of 2.5 on the inflation gap and 0.6 on the price level gap. The inflation target is set to $2 \%$ to match the Federal Reserve's current long-run inflation target. As is standard in the New-Keynesian literature, price elasticity and stickiness parameters are chosen to imply an average $25 \%$ markup and 2 quarters of price stickiness.

The correlation between long-run productivity shocks and inflation target shocks is negative away from the ZLB and uncorrelated at the ZLB. This matches the time-varying correlation between long-run expected productivity and expected inflation observed in the data. For example,

during the 1970's with high inflation, higher expected inflation was correlated with lower expected 
consumption growth; while during the Great Recession, lower expected inflation is not correlated with higher expected consumption growth.

\section{Unconditional Moments}

The model matches the unconditional means of consumption growth and labor. As in the data, inflation volatility is relatively higher compared to consumption growth and the correlation between consumption and inflation is positive on average.

For unconditional yields, the model does well in matching the level of the 3 month nominal yield and the upward sloping nominal yield, as measured by the spread between the 3 year and 3 month nominal yield. As in the data, the standard deviation of the spread is less than the short rate. With respect to real yields, the model matches the small but negative real yield spread. Standard deviations and autocorrelations of the 3 year minus 3 month real spread are less than the 3 month real yield. Finally, the model matches the upward sloping breakeven inflation spread and standard deviations of the 3 month breakeven inflation yield and spread.

With respect to excess returns, the model matches the high equity risk premium, positive nominal bond risk premium, and negative real bond risk premium. In addition, the model matches nominal bond excess return volatility, and implies less volatile real bond excess returns relative to nominal bond excess returns. The model replicates the unconditional correlations of excess returns between equity and bond markets. During normal times, nominal bond and breakeven inflation excess returns are positively correlated with equity excess returns while real excess are negatively correlated with equity excess returns.

The model is also consistent with the positive correlation between real yields and equity returns observed during the pre-Great Recession. Finally, the model matches both equity and real bond's responses to long-run productivity shocks. Pre-crisis, both real rates and equity returns would fall in response to negative long-run productivity declines.

\section{Great Recession Dynamics}

In terms of replicating the dynamics observed during the Great Recession, the model is fed filtered short and long-run productivity from the data over 2007Q4 to 2009Q1. Corresponding 
to Table 6.7, the dynamics are broken up into two subperiods. In the first period, labeled "Peakto-ZLB", the model replicates the dynamics that occurred in reaching the ZLB from $2007 \mathrm{Q} 4$ to 2008Q3. Cumulative productivity growth is negative and close to the $-1.42 \%$ empirical counterpart, cumulative inflation is low but positive, and labor growth is negative. With respect to prices, equity price, 3 month nominal yield, and 3 month real yields fall by $23 \%, 4.5 \%$, and $3.8 \%$ in the model compared to $23 \%, 3.5 \%$, and $2.6 \%$ in the data.

In the second period when the nominal rate is constrained at the ZLB, productivity growth and labor growth decrease by $13 \%$ and $11 \%$ in the model compared to $4.5 \%$ and $4.2 \%$ in the data. As in the data, cumulative consumption growth is negative and both the data and model experience deflation. With respect to prices, equity prices fall by $47 \%$ while the 3 month real yield rises $3 \%$ in the model compared to $78 \%$ and $3 \%$ in the data, respectively. Finally, the model predicts that the equity risk premium increases $0.74 \%$ at the ZLB relative to the unconditional equity risk premium.

\section{Time-Varying ZLB Moments}

The model is able to match conditional moments observed at the ZLB. With respect to quantities, inflation and labor growth become negatively skewed. Uncertainty of consumption growth, as measured by conditional volatility of expected consumption growth, increases. In addition, consumption and inflation become negatively correlated.

At the ZLB, the real bond's rate response to long-run productivity shocks reverses. While real rates fall in normal times in response to a negative long-run productivity shock, real rates rise at the ZLB in response to a negative long-run productivity shock. Equity returns continue to fall at the ZLB. This time-varying response for real bonds produces a time varying correlation between real bonds and equity markets. Using filtered productivity shocks from the Great Recession, the model produces a negative correlation between real bonds and equities, consistent with the observed negative correlation in the data.

In addition to the time-varying correlation, the ZLB produces asymmetric responses for equity returns in response to positive and negative long-run productivity shocks. Equity returns fall further in response to negative shocks than they rise in response to positive shocks. This increased 
downside risk results in a time-varying, increasing equity risk premium at the ZLB.

\section{ZLB Predictions}

Given that empirical observations of being at the ZLB are rare, it is important to appeal to structural models to help guide economists and policy makers' assessment of the these extreme times. The model makes two important predictions. First, the equity risk premium is increasing at the ZLB. This channel has been explained above and is driven by the endogenous increase in uncertainty of macrofundamentals created by the ZLB. Second, policy makers face the question if the ZLB is an important constraint. The Federal Reserve seeks to stabilize short-run fluctuations in labor markets while maintaining a long-run moderate and stable inflation rate. Ex-ante it is unclear as to if the central bank should care about the costs of being constrained at the ZLB in the face of declining long-run productivity growth. Given the short-run focus of the central bank, a natural question to ask is how costly is the ZLB relative to normal times when we think about the subsequent 5 year recovery period following a shock at the ZLB. Specifically, define

$$
\begin{aligned}
\hat{u}_{t+j} & =\ln \frac{\frac{\partial U_{t+j}}{\partial x_{t}}}{U_{t+j}} \\
\mathbb{L} & =\sum_{j=1}^{60}\left(\hat{u}_{t+j}^{Z L B}-\hat{u}_{t+j}^{S S}\right)
\end{aligned}
$$

$\hat{u}_{t+j}$ denotes the percent change in utility at time $t+j$ from a negative one standard deviation decline in long-run productivity at time $t . \hat{u}_{t+j}^{Z L B}-\hat{u}_{t+j}^{S S}$ denotes the percent difference in utility between the ZLB and stochastic steady state. Finally, summing up the difference over the next 60 months gives an estimate of the immediate cost following a period of constrained monetary policy. In the benchmark model, the increase in the cost is $1.74 \%$ utils. Hence the inability for the central bank to respond to long-run shocks at the ZLB has a moderate short-run cost and thus, per their mandate, should be apart of their broader policy making consideration. 


\section{Mechanisms}

ZLB

In the model, intertemporal allocations depend on two channels: a wage channel and a savings channel. In response to a negative long-run supply news shock, wages fall and households supply less labor. To counteract this via the savings channel, the central bank lowers the nominal interest rate to stimulate aggregate demand and increase demand for labor. On net, the wage channel dominates and labor declines. Declining labor implies declining marginal costs and falling inflation.

At the ZLB, monetary policy becomes constrained and cannot further stimulate the economy, resulting in a liquidity trap. Households foresee falling future prices and delay current consumption, decreasing current aggregate demand and further decreasing demand for labor. Thus in normal times, the savings channel counteracts the wage channel, while at the ZLB, the savings channel amplifies the effects of the wage channel. The liquidity trap at the ZLB results in larger declines in consumption, labor, and inflation with respect to negative long-run productivity news relative to normal times. Hence, the ZLB is characterized by negatively skewed and increasingly uncertain macrofundamentals.

Given the constraint of the ZLB, the real rate must rise to offset falling expected inflation. In equilibrium, future consumption growth increases due to the asymmetric response of labor's response to the liquidity trap. In response to a negative long-run supply shock at the ZLB, labor falls relatively more than in normal times. The negative skewness in the level of current labor implies positive future labor growth and hence positive future consumption growth. Increasing future consumption growth implies increasing future real rates via the nominal bond's Euler equation. Finally, as equity is modeled as a levered consumption claim in the model, the negatively skewed consumption growth at the ZLB results in negatively skewed and more volatile equity returns.

\section{EZ Preferences}

With respect to asset prices, liquidity traps at the ZLB result in an increasing equity risk pre-

mium. In response to the increased downside risk at the ZLB from negatively skewed equity returns, risk averse investors demand a higher equity risk premium. This implication is absent 
without Epstein Zin recursive preferences. Recursive preferences allow the IES to be disentangled from risk aversion. With CRRA preferences, risk aversion is equal the reciprocal of the IES. When the IES is less than 1, agents are relatively more impatient and the wealth effect dominates the substitution effect, implying counterfactually investors use equity claims to provide insurance against bad times. In this case, the model's equity risk premium is negative.

When the IES is greater than 1, the return to consumption falls in response to negative long-run supply news shocks, generating a positive equity risk premium. However, with CRRA preferences, risk aversion is less than 1 and the model's implications are muted as investors do not sufficiently price the downside risk. As discussed in Bansal and Yaron (2004) and Colacito, Ghysels, Meng, and Siwasarit (2016), when the IES and risk aversion are allowed to both be greater than 1, investors with EZ preferences dislike negatively skewed and increasing uncertain equity claims and command a higher risk premium relative to agents with CRRA preferences.

Holding risk aversion fixed at 10 and comparing the benchmark calibration to CRRA preferences where IES is $\frac{1}{10}$, a negative 3 standard deviation long-run productivity shock at the ZLB results in an increase in the equity risk premium by $0.40 \%$ and $0.01 \%$ for EZ and CRRA preferences, respectively. Hence having agents with EZ preferences is crucial to produce both qualitatively and quantitatively interesting asset pricing implications in response to the endogenous macroeconomic ZLB dynamics.

\section{Sensitivity Analysis}

No ZLB

When the ZLB is not enforced, the model fails to match the time-varying macroeconomic and asset pricing moments. In contrast to the data at the ZLB, labor and inflation are not negatively skewed, consumption and inflation remain positively correlated, real rates continue to fall in response to negative long-run productivity shocks, and real rates remain positively correlated with equity returns. Finally, the model without the ZLB does not predict an increase in the equity risk premium at the ZLB. 


\section{CRRA: IES $<1$}

With CRRA preferences, risk aversion is equal to the IES. Examining the impact of CRRA preferences when the IES is less than 1 and holding risk aversion to 10 , we see the model fails to qualitatively reproduce many unconditional and conditional moments. Counterfactually, the nominal yield spread, nominal bond risk premium, and equity premium are negative. In addition, the calibration produces real bond excess returns that are strongly positively correlated with equity excess returns while breakeven inflation excess returns are negatively correlated with equity excess returns. Finally, equity returns rise in response to negative long-run productivity shocks, resulting in a positive correlation between real bond rates and equity returns at the ZLB.

\section{CRRA: IES $>1$}

Examining the impact of CRRA preferences by holding the IES to 2, we see that the model produces quantitatively incorrect asset pricing moments. The nominal yield spread and equity premium are low at $0.01 \%$ and $0.15 \%$, while the nominal bond premium overshoots at $4.07 \%$. The model predicts a very small increase in the equity risk premium at the ZLB. With EZ preferences, agents care about time-varying uncertainty and negatively skewed returns. With CRRA preferences, this channel is absent and agents do not price the endogenous increasing macroeconomic uncertainty and negatively skewed consumption growth at the ZLB. Hence the increase in the equity premium is magnitudes smaller than compared with EZ preferences. In regards to welfare, with CRRA preferences such that the IES=2, the short-run cost of constrained monetary policy is 7 magnitudes smaller than compared to EZ preferences.

Long-Run Productivity and Inflation Target Correlation

As discussed in Piazzesi and Schneider (2007), negatively correlated consumption growth and inflation produces an upward sloping nominal yield curve. A positive correlation between inflation target shocks and long-run productivity shocks produces negatively correlated consumption and inflation, allowing the model to match unconditional nominal bond market moments. In addition, the positive correlation allows the model to replicate the positive correlation between nominal bond and equity excess returns observed in the data. 


\section{GHH Preferences \& Interest Rate Smoothing}

For robustness, other consumption-leisure bundle aggregators and monetary policy rules were considered. Specifically, GHH consumption-leisure bundle aggregators and Taylor rules with interest rate smoothing were explored. GHH preferences are commonly used in macroeconomics as there is no wealth effect on the labor supply. Interest rate smoothing is also commonly used in monetary policy models under the argument that the central bank seeks to smooth its policy implementation over time. Unfortunately, calibrations that produce empirically consistent estimates when the ZLB is not enforced fail to result in an equilibrium when the ZLB is enforced. This is a common issue in the ZLB literature and has been explored in Fernández-Villaverde et al. (2015). The ZLB is characterized by falling inflation. At the ZLB, falling inflation causes depressed labor today, which results in a higher future consumption growth rate, such that the real rate rises to offset falling expected inflation in the nominal bond Euler equation. However, in equilibrium, inflation is the discounted sum of marginal costs from the firm's price setting decision. Falling labor results in declining marginal costs, which further depresses inflation. Falling inflation than further depresses labor, resulting in a deflationary spiral. Given the calibration, the deflationary spiral may be so extreme that an equilibrium is prevented. This was the case when GHH preferences and interest rate smoothing was explored with calibrations similar to the benchmark. 


\section{CHAPTER 5: CONCLUSION}

I show that in a New-Keynesian model subject to the zero lower bound (ZLB), constrained monetary policy endogenously results in increasing risk premium and time-varying equity-bond market correlations. Liquidity traps at the ZLB are characterized by negatively skewed consumption growth, labor growth, and inflation. Negatively skewed consumption growth results in negatively skewed equity returns. Investors with recursive preferences price the increased downside risk, resulting in a greater equity risk premium. While real bond yields fall in response to productivity declines in normal times, real bond yields increase at the ZLB in response to falling expected inflation. Hence, equity returns and real bond yields become negatively correlated at the ZLB, while positive in normal times.

These implications are empirically consistent with the comovement of macrofundamentals and asset prices observed during the Great Recession. The model helps to explain why real bonds ceased to provide investors insurance during the Great Recession, precisely when they valued it most. Finally, the model predicts that equity risk premiums are increasing at the ZLB in response to endogenously negatively skewed labor growth resulting in greater downside risk. An important normative implication of this paper is that investors should optimally hold a combination of both real and nominal bonds in their investment portfolio. Real bonds hedge productivity declines in normal times while nominal bonds hedge deflation risk during recessions. 


\section{TABLES}

Table 6.1: Calibration

\begin{tabular}{lcc}
\hline \hline Preference Parameters & & \\
Subjective Discount Factor & $\beta$ & 0.985 \\
Intertemporal Elasticity of Substitution & $\psi$ & 2 \\
Risk Aversion & $\gamma$ & 10 \\
& & \\
Technology Parameters & $\mu$ & $2.75 \%$ \\
Mean of Productivity & $\rho_{a}$ & 0.85 \\
Persistence of Long-Run Risk & $\sigma_{a}$ & $0.70 \%$ \\
Volatility of Short-Run Productivity Shocks & $0.08 \%$ \\
Volatility of Long-Run Productivity Shocks & $\sigma_{x}$ & $0.2 \%$ \\
Volatility of Monetary Policy Shocks & $\sigma_{i}$ & $0.3 \%$ \\
Volatility of Price Level Shocks & $\sigma_{\pi}$ & $0.80\left(12 L B^{-1}\right)$ \\
Correlation of Long-Run Productivity & $\rho_{x, \pi}$ & \\
and Inflation Target Shocks & & \\
& & \\
Central Bank Parameters & & \\
Inflation Target & $\pi$ & $2 \%$ \\
Interest Rate Smoothing & $\rho_{I}$ & 0 \\
Output Gap & $\beta_{Y}$ & 0 \\
Inflation Gap & $\beta_{\pi}$ & 2.5 \\
Price Level Gap & $\beta_{P}$ & 0.6 \\
& & \\
New-Keynesian Parameters & & \\
Price Elasticity & $\eta$ & $50 \%$ \\
Price Stickiness & & \\
\hline
\end{tabular}

The model is calibrated at a monthly frequency. Annualized parameter values are presented. 
Table 6.2: Macroeconomic Quantity Statistics

\begin{tabular}{lccc}
\hline \hline & & Data & Model \\
\hline Means & & & \\
Consumption Growth & $E[\Delta c]$ & $2.75 \%$ & $2.75 \%$ \\
& & $(0.29 \%)$ & \\
Inflation & $E[\pi]$ & $4.08 \%$ & $2.00 \%$ \\
& & $(0.79 \%)$ & \\
Labor & $E[N]$ & $0.22 \%$ & $0.22 \%$ \\
& & $(0.003 \%)$ &
\end{tabular}

\section{Standard Deviations}

$\begin{array}{llcc}\text { Consumption Growth } & \sigma(\Delta c) & \begin{array}{c}0.90 \% \\ (0.08 \%)\end{array} & 1.27 \% \\ \text { Inflation } & & \begin{array}{c}1.71 \% \\ \end{array} & 1.47 \% \\ \text { Labor Growth } & \sigma(\pi) & (0.27 \%) & \\ & \sigma(\Delta N) & 1.41 \% & 0.86 \% \\ & & (0.12 \%) & \end{array}$

\begin{tabular}{lccc} 
Autocorrelations & & & \\
Consumption Growth & $\rho(\Delta c)$ & 0.52 & 0.19 \\
& & $(0.10)$ & \\
Inflation & $\rho(\pi)$ & 0.62 & 0.95 \\
& & $(0.15)$ & \\
Labor & $\rho(N)$ & 0.99 & 0.63 \\
& & $(0.10)$ & \\
\hline
\end{tabular}

Statistics calculated using quarterly data from 1971 to 2014. Means are annualized. Bootstrapped standard errors in parentheses. 
Table 6.3: Time-Varying Macroeconomic Quantity Statistics

\begin{tabular}{|c|c|c|c|c|c|}
\hline & \multicolumn{2}{|c|}{ Unconditional: 1971-2014 } & \multicolumn{2}{|c|}{ ZLB: 2008Q4-2014Q4 } \\
\hline & & Data & Model & Data & Model \\
\hline \multicolumn{6}{|l|}{ Standard Deviations } \\
\hline Expected Consumption & $\sigma(E[\Delta c])$ & $\begin{array}{c}0.67 \% \\
(0.08 \%)\end{array}$ & $0.40 \%$ & $\begin{array}{c}0.80 \% \\
(0.23 \%)\end{array}$ & $0.66 \%$ \\
\hline \multicolumn{6}{|l|}{ Skewness } \\
\hline Consumption Growth & $s k(\Delta c)$ & $\begin{array}{l}-0.41 \\
(0.22)\end{array}$ & -0.11 & $\begin{array}{l}-0.46 \\
(0.55)\end{array}$ & -0.79 \\
\hline Inflation & $\operatorname{sk}(\pi)$ & $\begin{array}{c}0.60 \\
(0.45)\end{array}$ & 0.09 & $\begin{array}{l}-1.96 \\
(1.25)\end{array}$ & -0.59 \\
\hline Labor Growth & $s k(\Delta n)$ & $\begin{array}{l}-0.56 \\
(0.35)\end{array}$ & -0.21 & $\begin{array}{l}-1.32 \\
(0.75)\end{array}$ & -1.83 \\
\hline \multicolumn{6}{|l|}{$\begin{array}{l}\text { Correlations w/ } \\
\text { Consumption Growth }\end{array}$} \\
\hline Inflation & $\rho(\Delta c, \pi)$ & $\begin{array}{l}-0.16 \\
(0.16)\end{array}$ & -0.54 & $\begin{array}{c}0.38 \\
(0.31)\end{array}$ & 0.49 \\
\hline Labor Growth & $\rho(\Delta c, \Delta n)$ & $\begin{array}{c}0.40 \\
(0.10)\end{array}$ & 0.66 & $\begin{array}{c}0.77 \\
(0.28)\end{array}$ & 0.74 \\
\hline
\end{tabular}

Statistics calculated using quarterly data from 1971 to 2014. Standard deviations are annualized. Standard deviation at the ZLB of expected consumption growth calculated using SPF analysts' forecasts of expected consumption growth over 2008Q4-2009Q1. Skewness and correlations at the ZLB in the data is sample statistic over 2008Q4-2014Q4. ZLB moments in the model is the conditional moment conditioned on being at the ZLB. Bootstrapped standard errors in parentheses. 
Table 6.4: Yield Statistics

\begin{tabular}{lcccc}
\hline \hline Maturity & \multicolumn{2}{c}{ 1Q } & \multicolumn{2}{c}{ 3Y-1Q } \\
& Data & Model & Data & Model \\
\hline Nominal Yields & & & & \\
Mean & $5.10 \%$ & $5.81 \%$ & $0.85 \%$ & $0.79 \%$ \\
& $(0.96 \%)$ & & $(0.13 \%)$ & \\
Standard Deviation & $3.43 \%$ & $2.72 \%$ & $0.88 \%$ & $1.46 \%$ \\
& $(0.58 \%)$ & & $(0.11 \%)$ & \\
Autocorrelation & 0.98 & 0.85 & 0.79 & 0.86 \\
& $(0.03)$ & & $(0.03)$ &
\end{tabular}

\section{Real Yields}

Mean

$\begin{array}{cccc}0.45 \% & 2.41 \% & -0.14 \% & -0.15 \% \\ (0.57 \%) & & (0.09 \%) & \end{array}$

Standard Deviation

$2.14 \% \quad 0.80 \% \quad 1.28 \% \quad 0.42 \%$

$(0.21 \%) \quad(0.15 \%)$

Autocorrelation

$\begin{array}{cccc}0.63 & 0.83 & 0.38 & 0.37 \\ (0.07) & & (0.04) & \end{array}$

\begin{tabular}{lcccc} 
Breakeven Inflation & & & & \\
Mean & $1.00 \%$ & $3.40 \%$ & $0.77 \%$ & $0.94 \%$ \\
& $(0.24 \%)$ & & $(0.13 \%)$ & \\
Standard Deviation & $2.14 \%$ & $2.88 \%$ & $1.33 \%$ & $1.31 \%$ \\
& $(0.33 \%)$ & & $(0.20 \%)$ & \\
Autocorrelation & 0.58 & 0.91 & 0.46 & 0.95 \\
& $(0.05)$ & & $(0.06)$ & \\
\hline
\end{tabular}

Statistics calculated using quarterly data from 1971 to 2014. Real and breakeven inflation yields data begin in March 2004. Bootstrapped standard errors in parentheses. 
Table 6.5: Excess Return Statistics

\begin{tabular}{lcc}
\hline \hline & Data & Model \\
\hline Means & & \\
Equity & $6.16 \%$ & $4.90 \%$ \\
& $(2.12 \%)$ & \\
Nominal Bond & $1.63 \%$ & $1.20 \%$ \\
& $(0.68 \%)$ & \\
Real Bond & $-0.24 \%$ & $-0.37 \%$ \\
& $(0.48 \%)$ & \\
Breakeven Inflation & $-0.02 \%$ & $1.58 \%$ \\
& $(0.40 \%)$ &
\end{tabular}

\section{Standard Deviations}

$\begin{array}{lcc}\text { Equity } & 14.76 \% & 9.34 \% \\ & (0.84 \%) & \\ \text { Nominal Bond } & 4.17 \% & 4.08 \% \\ & (0.46 \%) & \\ \text { Real Bond } & 1.93 \% & 0.80 \% \\ & (0.58 \%) & \\ \text { Breakeven Inflation } & 1.23 \% & 4.52 \% \\ & (0.68 \%) & \end{array}$

$\begin{array}{lcc}\begin{array}{l}\text { Correlations } \\ \text { w/ Equity }\end{array} & & \\ \text { Nominal Bond } & 0.23 & 0.73 \\ & (0.16 \%) & \\ \text { Real Bond } & -0.05 & -0.91 \\ & (0.09 \%) & \\ \text { Breakeven Inflation } & 0.35 & 0.81 \\ & (0.07 \%) & \\ \end{array}$

Statistics calculated using quarterly data from 1971 to 2007. Means and standard deviations are annualized. Data for real and breakeven inflation yields begin in March 2004. Bootstrapped standard errors in parentheses. 
Table 6.6: Time-Varying Return Statistics

\begin{tabular}{|c|c|c|c|c|}
\hline & \multicolumn{2}{|c|}{ "Pre-ZLB: 1971-2008Q3 } & \multicolumn{2}{|c|}{ ZLB: 2008Q4-2014Q4 } \\
\hline & Data & Model & Data & Model \\
\hline \multicolumn{5}{|l|}{ Standard Deviation } \\
\hline Equity Return & $\begin{array}{l}14.85 \\
(1.04)\end{array}$ & 8.94 & $\begin{array}{l}16.54 \\
(3.55)\end{array}$ & 9.68 \\
\hline \multicolumn{5}{|l|}{ Skewness } \\
\hline Equity Return & $\begin{array}{l}-0.26 \\
(0.27)\end{array}$ & 0.04 & $\begin{array}{l}-1.81 \\
(0.56)\end{array}$ & -0.19 \\
\hline \multicolumn{5}{|c|}{$\begin{array}{l}\text { Response to Long-Run } \\
\text { Productivity Shock }\end{array}$} \\
\hline Real Yield & $\begin{array}{c}0.37 \\
(0.36)\end{array}$ & 0.44 & $\begin{array}{l}-1.58 \\
(0.47)\end{array}$ & -0.31 \\
\hline Equity Return & $\begin{array}{c}1.66 \\
(0.40)\end{array}$ & 3.16 & $\begin{array}{c}3.32 \\
(1.61)\end{array}$ & 3.50 \\
\hline $\begin{array}{l}\text { Correlation between } \\
\text { Equity Return \& } \\
\text { Real Yield }\end{array}$ & $\begin{array}{c}0.23 \\
(0.16)\end{array}$ & 0.39 & $\begin{array}{l}-0.75 \\
(0.27)\end{array}$ & -0.67 \\
\hline
\end{tabular}

Statistics calculated using quarterly data. Means and standard deviations are annualized. Data for real and breakeven inflation yields begin in March 2004. Correlations at the ZLB in the model is the conditional correlation at the ZLB. Bootstrapped standard errors in parentheses for standard deviations, skewness, and correlations. For responses to long-run productivity shock, values reported are responses of 3 month real yield and equity return to a 1 standard deviation increase in filtered expected productivity growth shocks. 
Table 6.7: ZLB Dynamics

\begin{tabular}{lcccc}
\hline \hline & \multicolumn{2}{c}{ Peak-to-ZLB: 2007Q4-2008Q3 } & \multicolumn{2}{c}{ ZLB: 2008Q4-2009Q1 } \\
& Data & Model & Data & Model \\
\hline Quantities & & & & \\
Productivity & $-1.42 \%$ & $-2.38 \%$ & $-4.51 \%$ & $-12.97 \%$ \\
Consumption & $0.07 \%$ & $-2.92 \%$ & $-1.74 \%$ & $-24.00 \%$ \\
Inflation & $5.35 \%$ & $2.56 \%$ & $-6.57 \%$ & $-3.73 \%$ \\
Labor & $-1.68 \%$ & $-0.56 \%$ & $-4.18 \%$ & $-10.91 \%$ \\
& & & & \\
Prices & & & & \\
Nominal Rate & $-3.46 \%$ & $-4.54 \%$ & & \\
Real Rate & $-2.57 \%$ & $-3.79 \%$ & $6.37 \%$ & $2.95 \%$ \\
Equity Price & $-22.64 \%$ & $-27.15 \%$ & $-78.49 \%$ & $-47.17 \%$ \\
Equity Premium & & $4.87 \%$ & & $5.61 \%$ \\
\hline
\end{tabular}

Data are quarterly. Peak-to-ZLB is defined as change from 2007Q4 to 2008Q3. ZLB is defined as change from 2008Q4 to 2009Q1. Productivity, expected productivity, consumption, and inflation are cumulative growth rates. Labor and equity price are percent change in levels. Nominal and real rates are changes in 3 month yields. All values annualized. 
Table 6.8: Sensitivity Analysis: Part 1

\begin{tabular}{lcccc}
\hline \hline Moment & Data & Benchmark & No ZLB & CRRA:IES; \\
\hline Means of 3y-3m Spread & & & & \\
Nominal Yield & $0.85 \%$ & $0.79 \%$ & $0.93 \%$ & $-0.95 \%$ \\
Real Yield & $-0.14 \%$ & $-0.15 \%$ & $-0.17 \%$ & $-1.11 \%$ \\
Breakeven Inflation Yield & $0.77 \%$ & $0.94 \%$ & $1.10 \%$ & $0.16 \%$ \\
& & & & \\
Risk Premiums & & & & \\
Nominal Bond & $1.63 \%$ & $1.20 \%$ & $1.41 \%$ & $-2.29 \%$ \\
Real Bond & $-0.24 \%$ & $-0.37 \%$ & $-0.43 \%$ & $-2.77 \%$ \\
Breakeven Inflation & $1.17 \%$ & $1.58 \%$ & $1.84 \%$ & $0.48 \%$ \\
Equity Premium & $6.16 \%$ & $4.90 \%$ & $5.15 \%$ & $-2.84 \%$ \\
Equity Premium at ZLB & & $5.30 \%$ & $4.73 \%$ & $-14.89 \%$ \\
& & & & \\
Standard Deviation & & & & \\
Expected Consumption Growth & $0.67 \%$ & $0.33 \%$ & $0.32 \%$ & $0.03 \%$ \\
Equity Return & $14.85 \%$ & $8.96 \%$ & $9.27 \%$ & $70.12 \%$ \\
& & & & \\
Standard Deviation at ZLB & & & & \\
Expected Consumption Growth & $0.80 \%$ & $0.66 \%$ & $0.36 \%$ & $0.08 \%$ \\
Equity Return & $16.54 \%$ & $9.78 \%$ & $8.68 \%$ & $121.79 \%$ \\
& & & & \\
Skewness & & & & \\
Consumption & -0.50 & -0.01 & -0.03 & 0.03 \\
Inflation & 1.07 & 0.03 & 0.05 & 0.04 \\
Labor & -0.33 & -0.27 & -0.09 & -0.08 \\
Equity Return & -0.26 & 0.03 & -0.02 & 0.18 \\
& & & & \\
Skewness at ZLB & -0.46 & -1.46 & 0.01 & -0.71 \\
Consumption & -1.96 & -0.90 & -0.01 & -1.01 \\
Inflation & -1.32 & -2.04 & -0.05 & -0.91 \\
Labor & -1.81 & -0.18 & 0.11 & -0.14 \\
Equity Return & & & &
\end{tabular}

Unconditional statistics calculated using quarterly data from 1971 to 2014. ZLB statistics calculated over 2008Q4 to 20014Q4. ZLB in the model is defined as negative 3 standard deviation long-run productivity in excess of the ZLB. Means and risk premiums are annualized. 
Table 6.9: Sensitivity Analysis: Part 2

\begin{tabular}{|c|c|c|c|c|}
\hline Moment & Data & CRRA:IES; 1 & $\rho=\mathbf{0}$ & CES:f $=0.5$ \\
\hline \multicolumn{5}{|l|}{ Means of 3y-3m Spread } \\
\hline Nominal Yield & $0.85 \%$ & $0.04 \%$ & $-0.38 \%$ & $1.02 \%$ \\
\hline Real Yield & $-0.14 \%$ & $0.03 \%$ & $-0.25 \%$ & $-0.14 \%$ \\
\hline Breakeven Inflation Yield & $0.77 \%$ & $0.01 \%$ & $-0.13 \%$ & $1.16 \%$ \\
\hline \multicolumn{5}{|l|}{ Risk Premiums } \\
\hline Nominal Bond & $1.63 \%$ & $0.05 \%$ & $-0.72 \%$ & $1.54 \%$ \\
\hline Real Bond & $-0.24 \%$ & $0.04 \%$ & $-0.51 \%$ & $-0.42 \%$ \\
\hline Breakeven Inflation & $1.17 \%$ & $0.01 \%$ & $-0.20 \%$ & $1.96 \%$ \\
\hline Equity Premium & $6.16 \%$ & $0.03 \%$ & $4.88 \%$ & $5.33 \%$ \\
\hline Equity Premium at ZLB & & $0.04 \%$ & $5.44 \%$ & $4.72 \%$ \\
\hline \multicolumn{5}{|l|}{ Standard Deviation } \\
\hline Expected Consumption Growth & $0.67 \%$ & $0.33 \%$ & $0.38 \%$ & $0.09 \%$ \\
\hline Equity Return & $14.85 \%$ & $10.16 \%$ & $9.24 \%$ & $9.78 \%$ \\
\hline \multicolumn{5}{|l|}{ Standard Deviation at ZLB } \\
\hline Expected Consumption Growth & $0.80 \%$ & $0.40 \%$ & $0.56 \%$ & $0.12 \%$ \\
\hline Equity Return & $16.54 \%$ & $9.90 \%$ & $10.27 \%$ & $9.80 \%$ \\
\hline \multicolumn{5}{|l|}{ Skewness } \\
\hline Consumption & -0.50 & -0.04 & -0.12 & 0.04 \\
\hline Inflation & 1.07 & 0.13 & -0.06 & 0.08 \\
\hline Labor & -0.33 & -0.07 & -0.07 & -0.04 \\
\hline Equity Return & -0.26 & 0.07 & -0.06 & -0.01 \\
\hline \multicolumn{5}{|l|}{ Skewness at ZLB } \\
\hline Consumption & -0.46 & -1.24 & -1.07 & -0.29 \\
\hline Inflation & -1.96 & -0.60 & -0.62 & -0.51 \\
\hline Labor & -1.32 & -1.92 & -1.65 & -1.86 \\
\hline Equity Return & -1.81 & -0.13 & -0.30 & -0.12 \\
\hline
\end{tabular}

Unconditional statistics calculated using quarterly data from 1971 to 2014. ZLB statistics calculated over 2008Q4 to 20014Q4. ZLB in the model is defined as negative 3 standard deviation long-run productivity in excess of the ZLB. Means and risk premiums are annualized. 
Table 6.10: Sensitivity Analysis: Part 3

\begin{tabular}{lcccc}
\hline \hline Moment & Data & Benchmark & No ZLB & CRRA:IES;1 \\
\hline Welfare Cost at ZLB & & $1.73 \%$ & $0.00 \%$ & $20.98 \%$ \\
Utils & & & & \\
& & & & \\
Correlations w/ & & & & \\
Consumption Growth & -0.16 & -0.55 & -0.53 & -0.13 \\
Inflation & 0.38 & 0.51 & -0.52 & 0.72 \\
Inflation at ZLB & & & & \\
& & & & \\
Correlations w/ & & & & \\
Equity Excess Return & 0.23 & 0.71 & 0.71 & 0.98 \\
Nominal Excess Return & -0.05 & -0.91 & -0.93 & 0.99 \\
Real Excess Return & 0.35 & 0.81 & 0.80 & -0.74 \\
Breakeven Inflation Excess Return & & & & \\
& & & & \\
Response to & & & & - \\
Long-Run Productivity Shock & + & + & + & - \\
Equity Return & + & + & + & - \\
Equity Return at ZLB & + & + & + & - \\
Real Yield & - & - & + & 0.01 \\
Real Yield at ZLB & 0.44 & 0.39 & 0.52 & 0.71 \\
Corr(Equity,Real) & -0.54 & -0.46 & 0.21 & \\
Corr(Equity,Real) at ZLB & & & & \\
\hline
\end{tabular}

Unconditional statistics calculated using quarterly data from 1971 to 2014. ZLB statistics calculated over 2008Q4 to 20014Q4. ZLB in the model is defined as negative 3 standard deviation long-run productivity in excess of the ZLB. Means and risk premiums are annualized. 
Table 6.11: Sensitivity Analysis: Part 4

\begin{tabular}{lcccc}
\hline \hline Moment & Data & CRRA:IES ; $^{1}$ & $\rho=0$ & CES:f=0.5 \\
\hline Welfare Cost at ZLB & & & & \\
Utils & & $0.25 \%$ & $1.03 \%$ & $0.38 \%$ \\
& & & & \\
Correlations w/ & & & & \\
Consumption Growth & -0.16 & -0.54 & 0.05 & -0.44 \\
Inflation & 0.38 & 0.09 & 0.37 & -0.04 \\
Inflation at ZLB & & & & \\
& & & & \\
Correlations w/ & & & & \\
Equity Excess Return & 0.23 & 0.71 & -0.03 & 0.77 \\
Nominal Excess Return & -0.05 & -0.92 & -0.86 & -0.79 \\
Real Excess Return & 0.35 & 0.80 & 0.17 & 0.85 \\
Breakeven Inflation Excess Return & & & & \\
& & & & \\
Response to & & & & \\
Long-Run Productivity Shock & + & + & + & + \\
Equity Return & + & + & + & + \\
Equity Return at ZLB & + & + & + & + \\
Real Yield & - & - & - & - \\
Real Yield at ZLB & -.44 & 0.52 & 0.07 & 0.45 \\
Corr(Equity,Real) & -0.54 & -0.49 & -0.43 & -0.22 \\
Corr(Equity,Real) at ZLB & & & & \\
\hline
\end{tabular}

Unconditional statistics calculated using quarterly data from 1971 to 2014. ZLB statistics calculated over 2008Q4 to 20014Q4. ZLB in the model is defined as negative 3 standard deviation long-run productivity in excess of the ZLB. Means and risk premiums are annualized. 
Table 6.12: Taylor Rule Estimation

\begin{tabular}{lccc}
\hline \hline Policy Parameter & & & \\
\hline Interest Rate Smoothing & $\rho_{i}$ & & 0.88 \\
& & & $(0.03)$ \\
Output Gap & $\beta_{Y}$ & -0.02 & 0.15 \\
& & $(0.13)$ & $(0.05)$ \\
Inflation Gap & $\beta_{\pi}$ & 2.47 & 0.63 \\
& & $(0.26)$ & $(0.13)$ \\
Price Level Gap & $\beta_{P}$ & 0.62 & -0.01 \\
& & $(0.19)$ & $(0.08)$ \\
\hline
\end{tabular}

Statistics calculated using quarterly data from 1971 to 2007 . Federal funds rate is used as the policy rate. Output gap is defined as log real potential GDP minus log real GDP from FRED. Price level gap is defined as deviations of the log price level from HP filtered log price level. Standard errors in parentheses. One, two, and three stars denote significance at the 10\%, 5\%, and $1 \%$ levels. 


\section{FIGURES}

Figure 7.1: Quantities
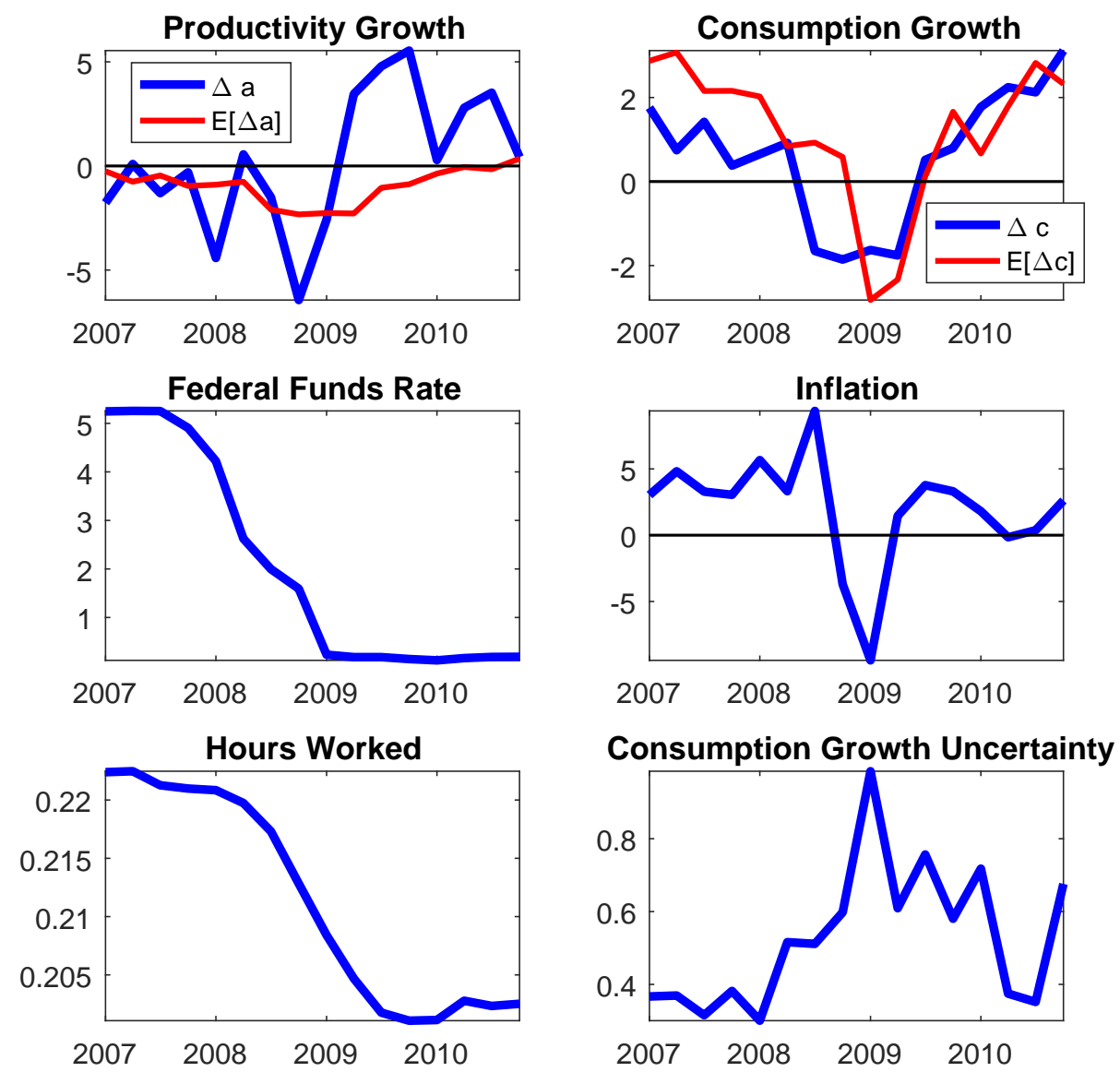

Quarterly data plotted. Growth rates are annualized. Total hours are normalized to one, and hours worked are plotted. 
Figure 7.2: Returns
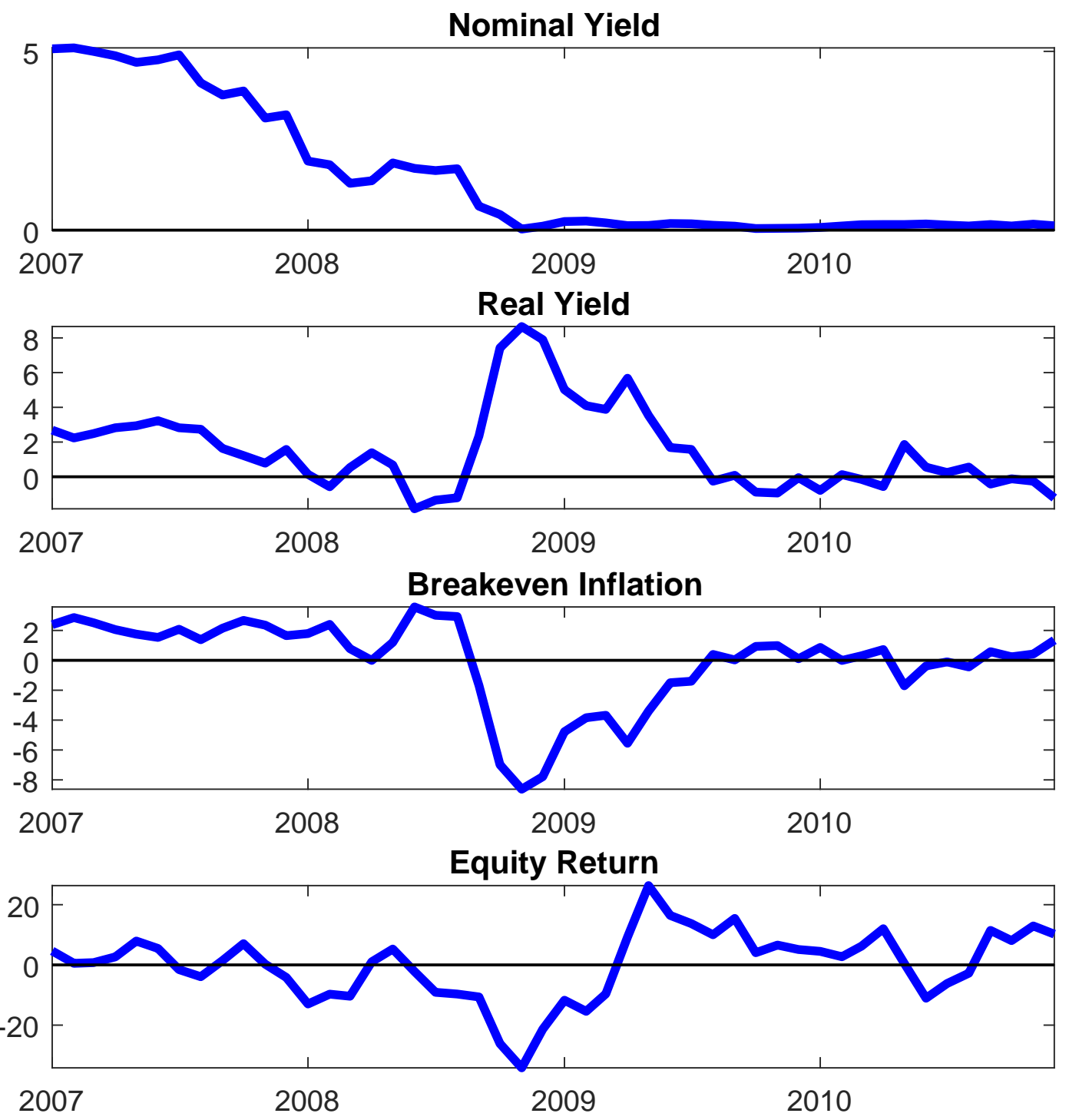

Quarterly 3-month yields and equity returns plotted. 
Figure 7.3: IRF: Quantities
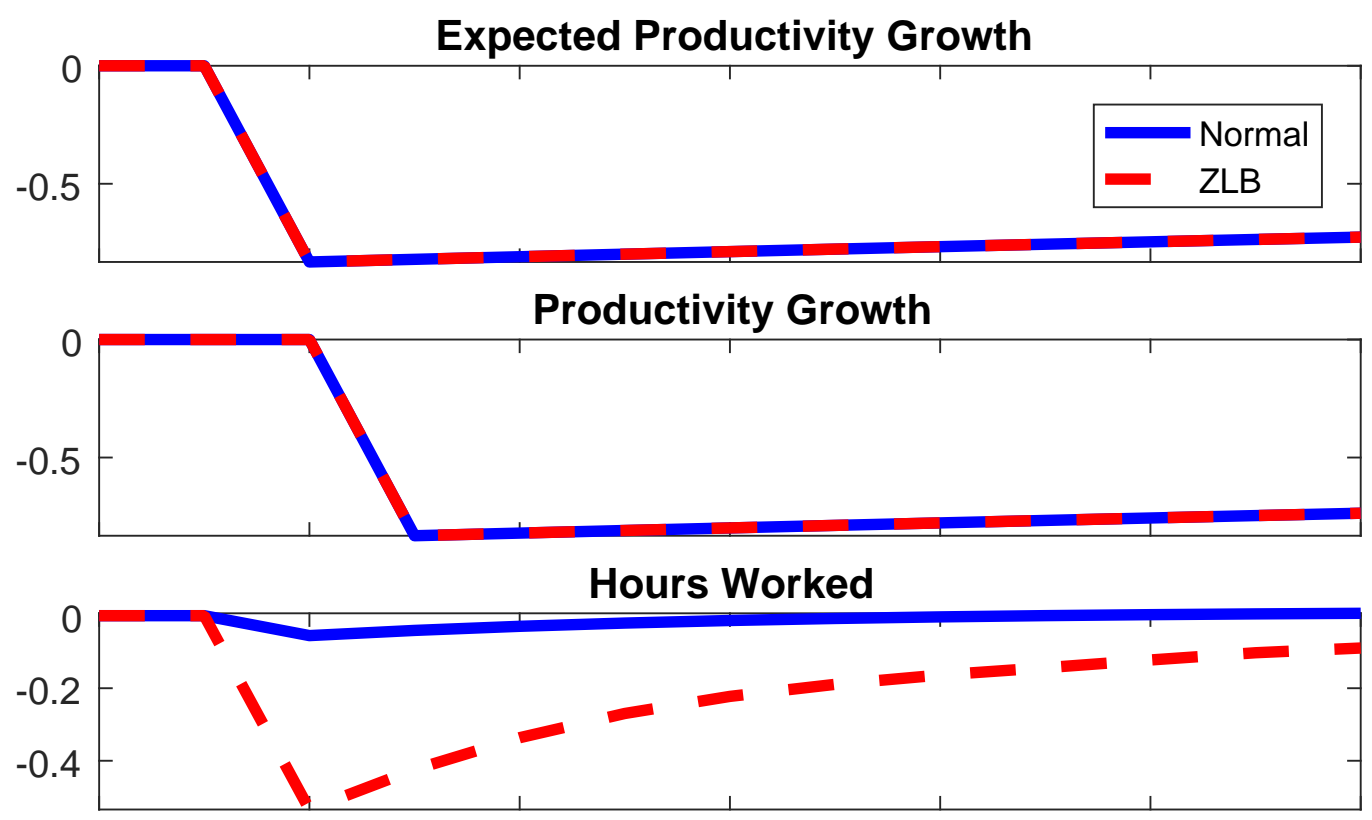

Consumption Growth
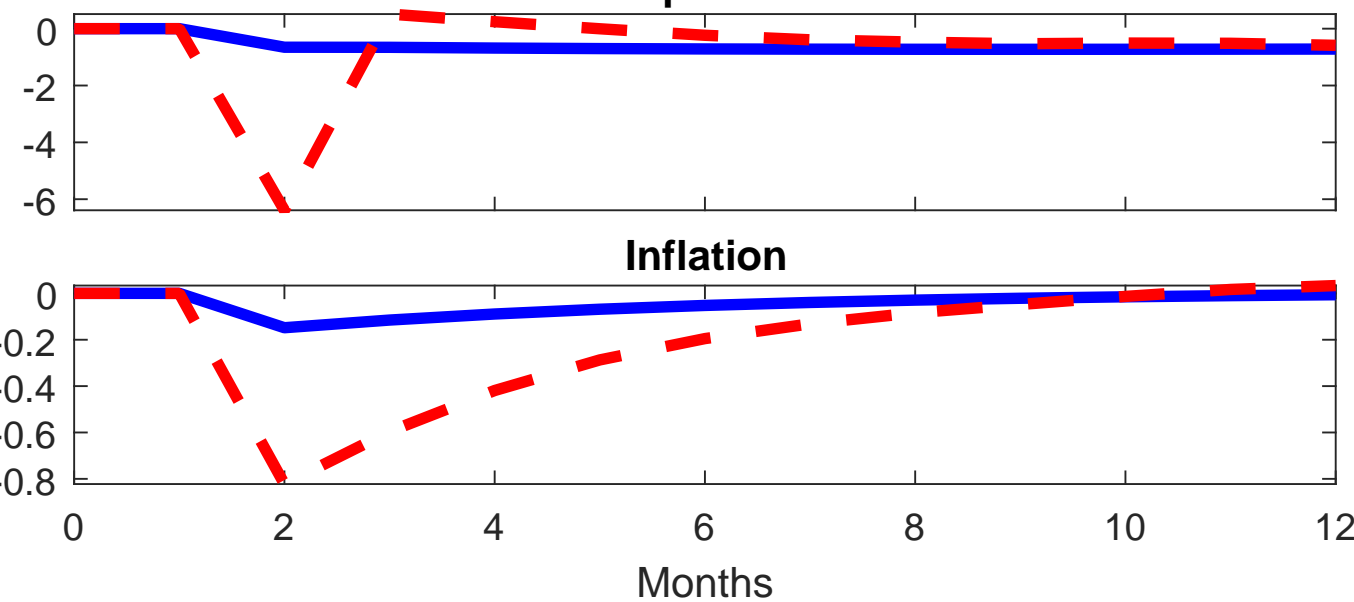

Impulse response functions with respect to a 1 standard deviation negative long-run productivity news shock. Shocks occur in time period 1. "Normal" ("ZLB") refers to the response of the model when it is at the stochastic steady state (ZLB). "Normal" is demeaned while responses in "ZLB" are relative to mean-reverting trends. All rates annualized. 
Figure 7.4: IRF: Fisher Decomposition
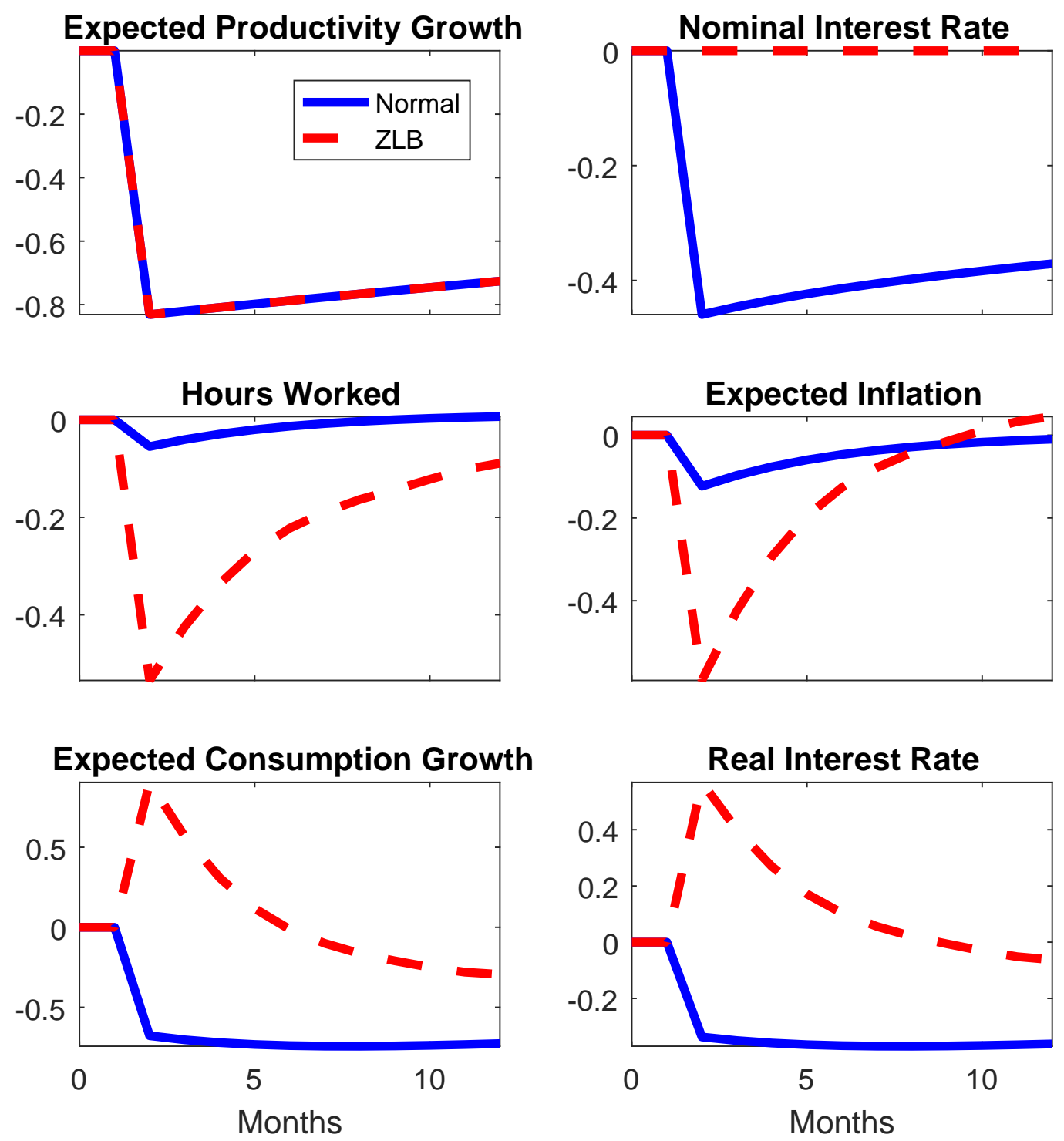

Impulse response functions with respect to a 1 standard deviation negative long-run productivity news shock. Shocks occur in time period 1. "Normal" ("ZLB") refers to the response of the model when it is at the stochastic steady state (ZLB). "Normal" is demeaned while responses in "ZLB" are relative to mean-reverting trends. All rates annualized. 
Figure 7.5: IRF: Returns
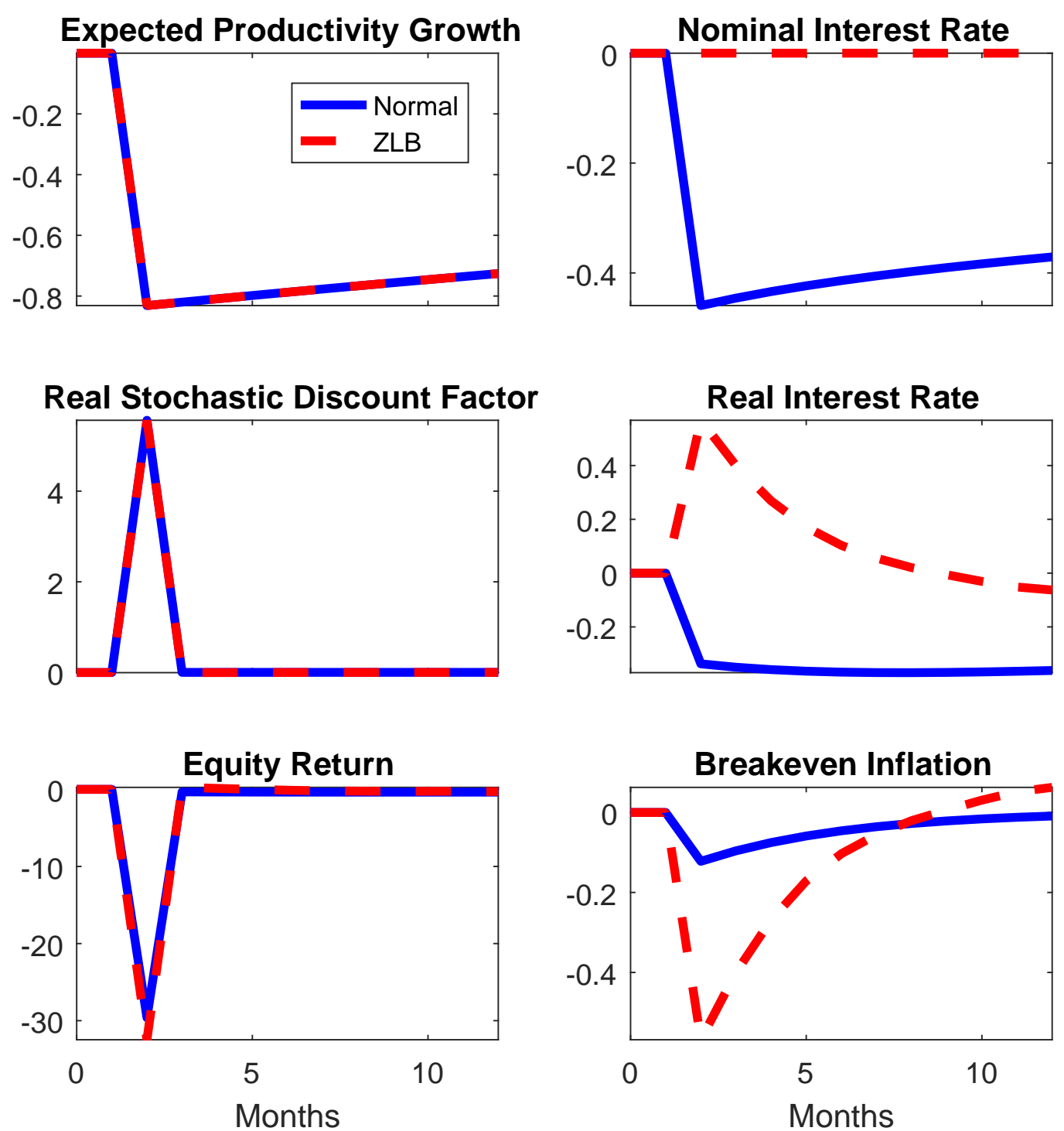

Impulse response functions with respect to a 1 standard deviation negative long-run productivity news shock. Shocks occur in time period 1. "Normal" ("ZLB") refers to the response of the model when it is at the stochastic steady state (ZLB). "Normal" is demeaned while responses in "ZLB" are relative to mean-reverting trends. All rates annualized. 
Figure 7.6: IRF: Stochastic Discount Factor
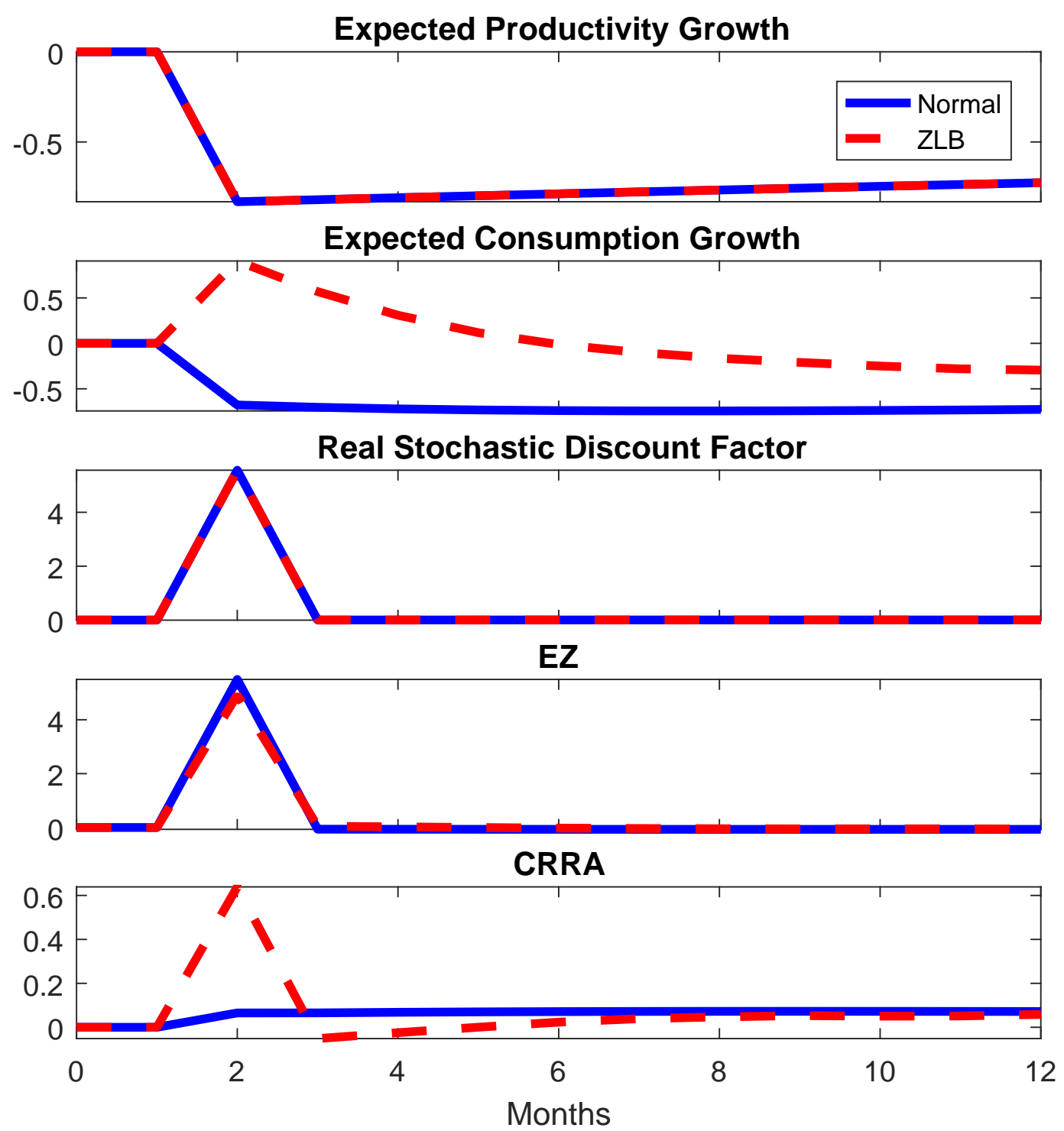

Impulse response functions with respect to a 1 standard deviation negative long-run productivity news shock. Shocks occur in time period 1. "Normal" ("ZLB") refers to the response of the model when it is at the stochastic steady state (ZLB). "Normal" is demeaned while responses in "ZLB" are relative to mean-reverting trends. All rates annualized. 
Figure 7.7: IRF: Consumption Growth Moments

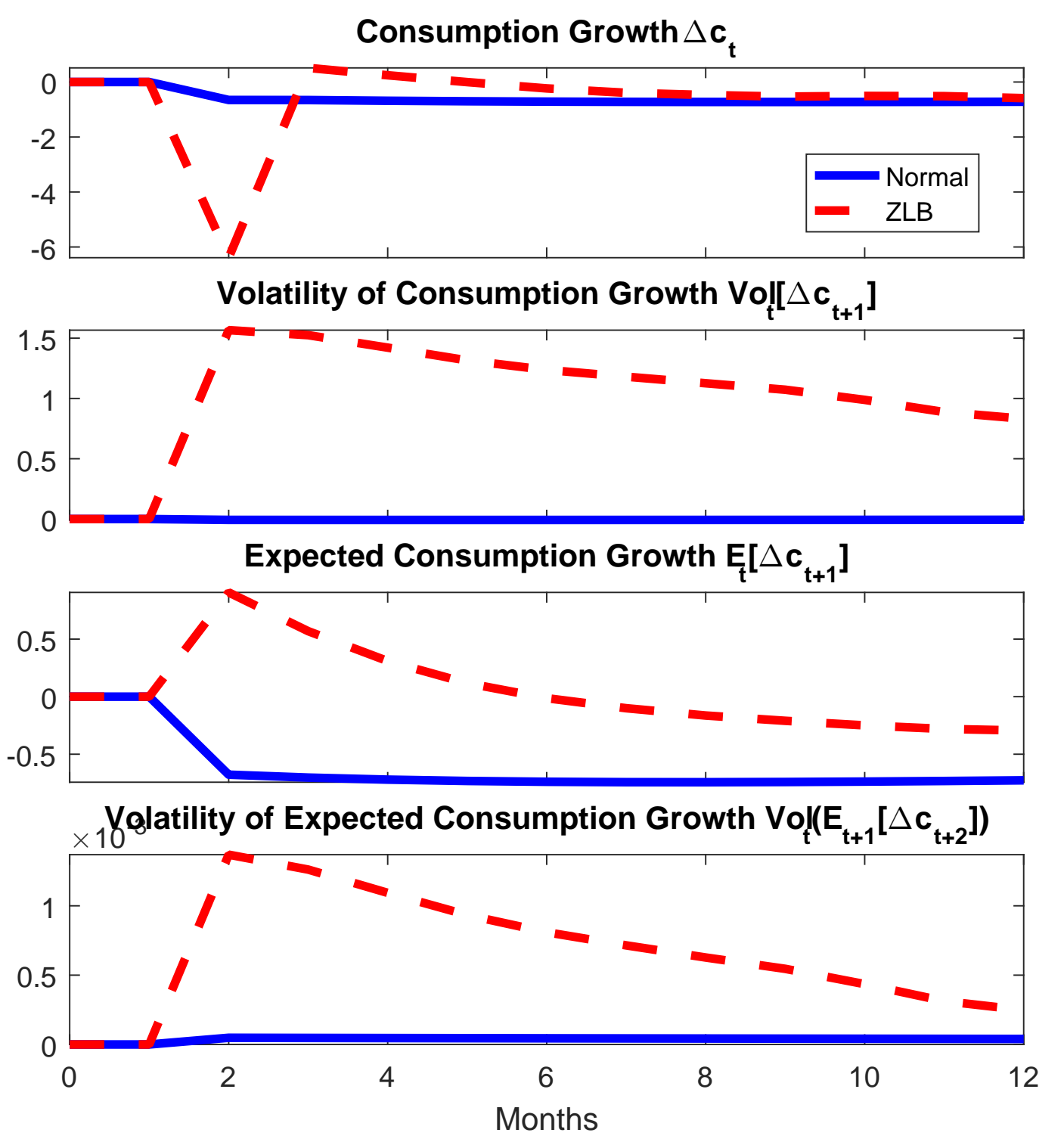

Impulse response functions with respect to a 1 standard deviation negative long-run productivity news shock. Shocks occur in time period 1. "Normal" ("ZLB") refers to the response of the model when it is at the stochastic steady state (ZLB). "Normal" is demeaned while responses in "ZLB" are relative to mean-reverting trends. All rates annualized. 
Figure 7.8: IRF: Equity Risk Premium
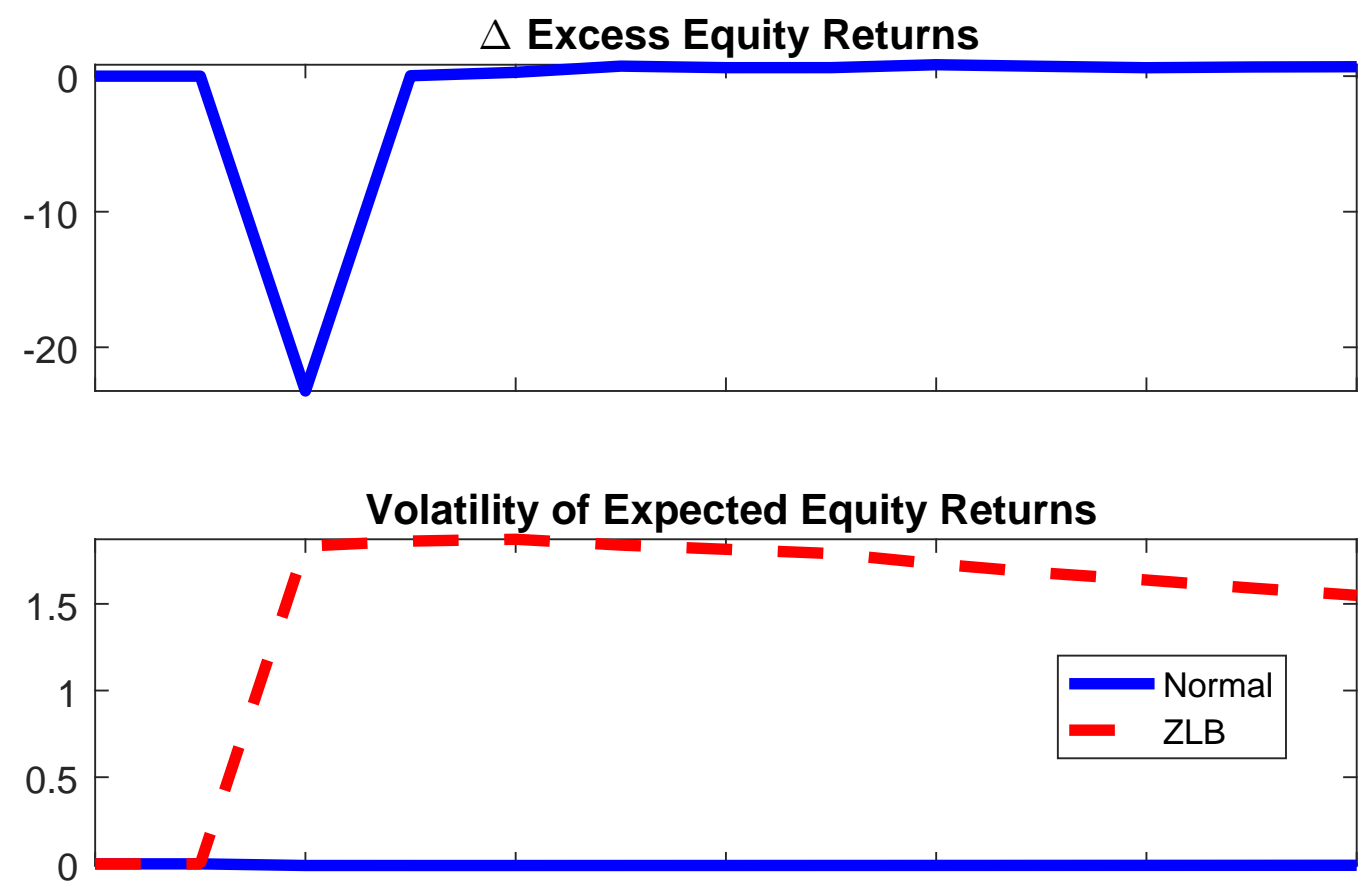

\section{Equity Risk Premium}

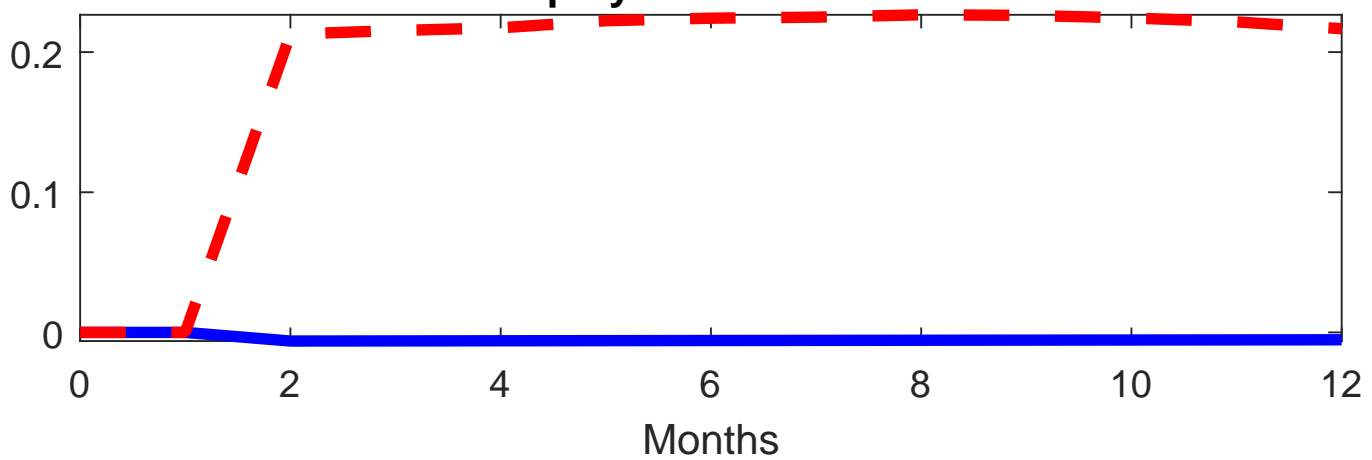

Impulse response functions with respect to a 1 standard deviation negative long-run productivity news shock. Shocks occur in time period 1. "Normal" ("ZLB") refers to the response of the model when it is at the stochastic steady state (ZLB). "Normal" is demeaned while responses in "ZLB" are relative to mean-reverting trends. All rates annualized. 


\section{APPENDIX A: ROBUSTNESS STATISTICS}

Table A.1: Yield Statistics Implied by Inflation Swaps

\begin{tabular}{lcc}
\hline \hline Maturity & $\mathbf{1 Q}$ & $\mathbf{3 Y - 1 Q}$ \\
\hline Real Yields & & \\
Mean & $-0.18 \%$ & $0.18 \%$ \\
& $(0.51 \%)$ & $(0.04 \%)$ \\
Standard Deviation & $3.26 \%$ & $1.47 \%$ \\
& $(0.16 \%)$ & $(0.07 \%)$ \\
Autocorrelation & 0.77 & 0.43 \\
& $(0.07 \%)$ & $(0.07 \%)$ \\
Breakeven Inflation & & \\
Mean & $1.63 \%$ & $0.44 \%$ \\
& $(0.20 \%)$ & $(0.08 \%)$ \\
Standard Deviation & $2.82 \%$ & $0.73 \%$ \\
& $(0.23 \%)$ & $(0.11 \%)$ \\
Autocorrelation & 0.67 & 0.58 \\
& $(0.06 \%)$ & $(0.08 \%)$ \\
\hline
\end{tabular}

Statistics calculated using quarterly data from April 2004 to 2014. Bootstrapped standard errors in parentheses. 
Table A.2: Excess Return Statistics Implied by Inflation Swaps

\begin{tabular}{lc}
\hline \hline & Data \\
\hline Means & $-0.22 \%$ \\
Real Bond & $(0.39 \%)$ \\
& $-0.04 \%$ \\
Breakeven Inflation & $(0.31 \%)$ \\
& \\
Standard Deviations & $2.61 \%$ \\
Real Bond & $(0.50 \%)$ \\
& $2.41 \%$ \\
Breakeven Inflation & $(0.55 \%)$ \\
& \\
Correlations w/ Equity Market & -0.36 \\
Real Bond & $(0.09 \%)$ \\
& 0.53 \\
Breakeven Inflation & $(0.07 \%)$ \\
&
\end{tabular}

Means and standard deviations are annualized. Statistics calculated using quarterly data from April 2004 to 2014. Bootstrapped standard errors in parentheses. 
Table A.3: Time-Varying Return Statistics Implied by Inflation Swaps

\begin{tabular}{lcc}
\hline \hline & Pre-ZLB: 2004-2008Q3 & ZLB: 2008Q4-2014Q4 \\
\hline $\begin{array}{l}\text { Response to Long-Run } \\
\text { Productivity Shock }\end{array}$ & & \\
Real Yield & 0.36 & -0.85 \\
& $(0.34)$ & $(0.30)$ \\
& & -0.61 \\
Correlation between & 0.41 & $(0.20)$ \\
$\begin{array}{l}\text { Equity Return \& } \\
\text { Real Yield }\end{array}$ & $(0.11)$ & \\
\hline
\end{tabular}

Statistics calculated using quarterly data. Data for inflation swaps begin in April 2004. Standard errors in parentheses. For responses to long-run productivity shock, values reported are responses of 3 month real yield to a 1 standard deviation increase in filtered expected productivity growth shocks. 


\section{APPENDIX B: EULER ERRORS}

Figure B.1: Nominal Bond Euler Errors

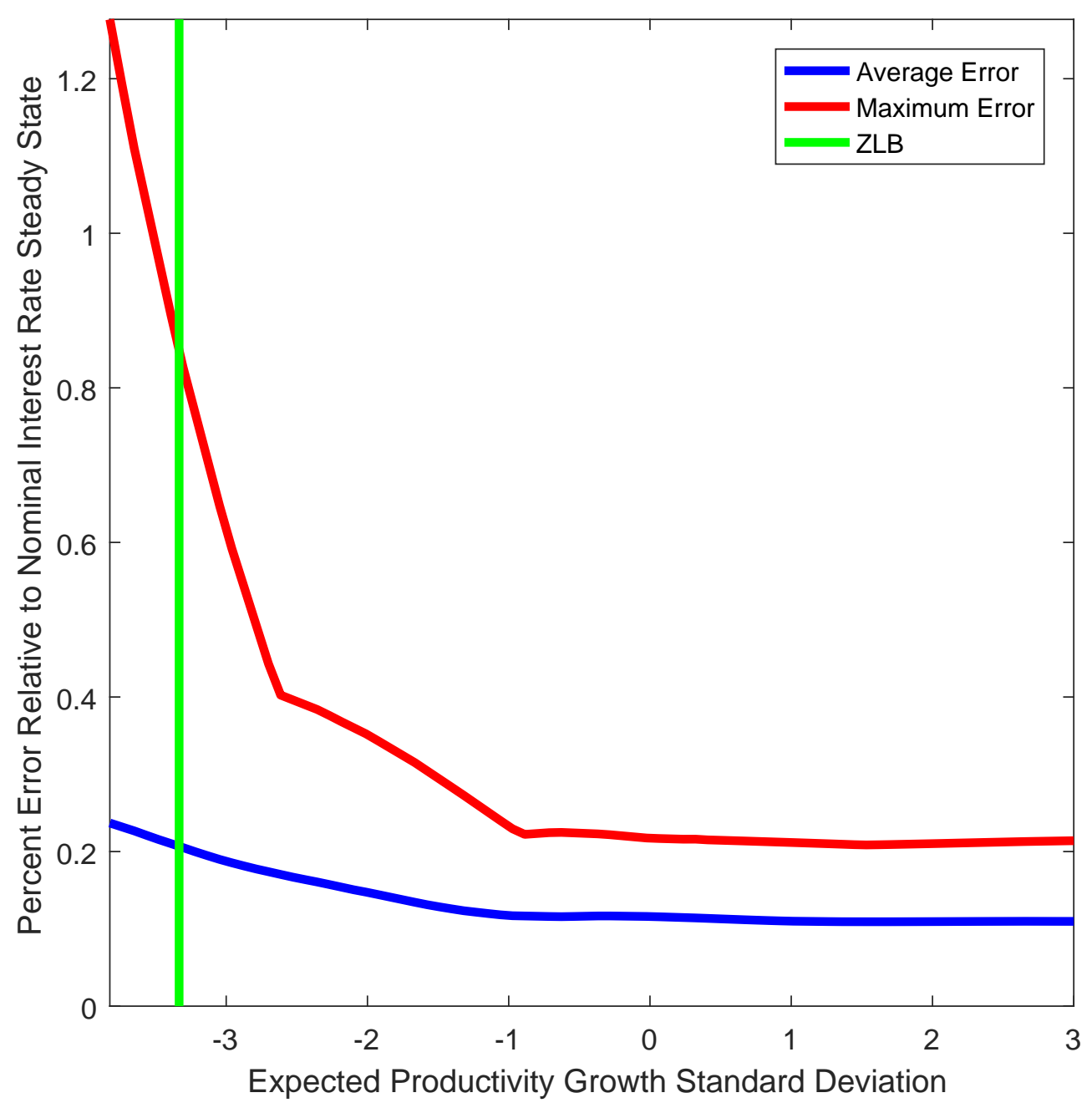

Relative nominal bond euler errors plotted as a function of the state variable expected productivity growth. X-axis units are in terms of standard deviation of expected productivity growth. In green is the first occurrence of the ZLB when the model is shocked with negative long-run productivity shocks. 


\section{APPENDIX C: MODEL DERIVATION}

\section{Households}

Households choose consumption $C_{t}$, leisure $L_{t}$, nominal bond holdings $B_{t}$, and labor supply $N_{t}$ to maximize lifetime utility $U_{0}$, where

$$
\begin{aligned}
& U_{t}=\left[(1-\beta) \tilde{C}_{t}^{1-\frac{1}{\psi}}+\beta E_{t}\left[U_{t+1}^{1-\gamma}\right]^{\frac{1-\frac{1}{\psi}}{1-\gamma}}\right]^{\frac{1}{1-\frac{1}{\psi}}} \\
& \tilde{C}_{t}=\left\{\begin{array}{cc}
{\left[\varphi C_{t}^{1-\frac{1}{f}}+(1-\varphi)\left(A_{t} L_{t}\right)^{1-\frac{1}{f}}\right]^{\frac{1}{1-\frac{1}{f}}}} & \mathrm{CES} \\
C_{t}^{\varphi}\left(A_{t} L_{t}\right)^{1-\varphi} & \mathrm{CD} f=1 \\
C_{t}-\varphi A_{t} \frac{N_{t}^{1+\frac{1}{f}}}{1+\frac{1}{f}} & \mathrm{GHH}
\end{array}\right. \\
& 1 \geq N_{t}+L_{t}
\end{aligned}
$$

where $A_{t}$ denotes labor-augmenting productivity. The household's budget constraint is

$$
P_{t} C_{t}+Q_{t} B_{t+1} \leq B_{t}+W_{t} N_{t}
$$

The household takes the price of consumption $P_{t}$, the price of nominal bonds $Q_{t}$, and the nominal wage rate $W_{t}$ as given. Nominal bonds are discount bonds and payoff $\$ B_{t}$ dollars at time $t$. The price of the nominal bond is the invesrse of the nominal interest rate, $Q_{t}=I_{t}^{f-1}$. The Lagrangian is

$$
\begin{aligned}
\mathscr{L} & =U_{0} \\
& +\cdots \\
& +\lambda_{1, t}\left[B_{t}+W_{t} N_{t}-P_{t} C_{t}-Q_{t} B_{t+1}\right] \\
& +\lambda_{2, t}\left[1-N_{t}-L_{t}\right] \\
& +\cdots
\end{aligned}
$$


The FOC w.r.t. consumption is

$$
\begin{aligned}
\frac{\partial \mathscr{L}}{\partial C_{t}} & =\frac{\partial U_{0}}{\partial C_{t}}-\lambda_{1, t} P_{t}=0 \\
\lambda_{1, t} P_{t} & =\frac{\partial U_{0}}{\partial C_{t}}
\end{aligned}
$$

The real SDF is

$$
\begin{aligned}
& M_{t+1}= \frac{\partial U_{0} / \partial C_{t+1}}{\partial U_{0} / \partial C_{t}} \\
&=\left\{\begin{array}{cc}
\beta \Delta \tilde{C}_{t+1}^{\frac{1}{f}-\frac{1}{\psi}} \Delta C_{t+1}^{-\frac{1}{f}}\left(\frac{U_{t+1}}{E_{t}\left[U_{t+1}^{1-\gamma}\right]^{\frac{1}{1-\gamma}}}\right)^{\frac{1}{\psi}-\gamma} & \mathrm{CES} \\
\beta \Delta C_{t+1}^{-\frac{1}{\psi}}\left(\frac{U_{t+1}}{E_{t}\left[U_{t+1}^{1-\gamma}\right]^{1-\gamma}}\right)^{\frac{1}{\psi}-\gamma} & \mathrm{CD} f=1 \\
\beta \Delta \tilde{C}_{t+1}^{-\frac{1}{\psi}}\left(\frac{U_{t+1}}{E_{t}\left[U_{t+1}^{1-\gamma}\right]^{\frac{1}{1-\gamma}}}\right)^{\frac{1}{\psi}-\gamma} & \mathrm{GHH}
\end{array}\right.
\end{aligned}
$$

The FOC w.r.t. leisure is

$$
\begin{aligned}
\frac{\partial \mathscr{L}}{\partial L_{t}} & =\frac{\partial U_{0}}{\partial L_{t}}-\lambda_{2, t}=0 \\
\lambda_{2, t} & =\frac{\partial U_{0}}{\partial L_{t}}
\end{aligned}
$$

The FOC w.r.t. labor is

$$
\begin{aligned}
\frac{\partial \mathscr{L}}{\partial N_{t}} & =\lambda_{1, t} W_{t}-\lambda_{2, t}=0 \\
W_{t} & =\frac{\lambda_{2, t}}{\lambda_{1, t}}
\end{aligned}
$$


The FOC w.r.t. nominal bonds is

$$
\begin{aligned}
\frac{\partial \mathscr{L}}{\partial B_{t+1}} & =E_{t}\left[\lambda_{1, t+1}\right]-Q_{t} \lambda_{1, t}=0 \\
Q_{t} & =E_{t}\left[\frac{\lambda_{1, t+1}}{\lambda_{1, t}}\right] \\
& =E_{t}\left[\frac{M_{t+1}}{\prod_{t+1}}\right]
\end{aligned}
$$

where $\Pi_{t+1}=\frac{P_{t+1}}{P_{t}}$ is the inflation rate. The real and nominal Euler bond equations are

$$
\begin{aligned}
R_{t}^{f} & =E_{t}\left[M_{t+1}\right]^{-1} \\
I_{t}^{f} & =E_{t}\left[\frac{M_{t+1}}{\Pi_{t+1}}\right]^{-1}
\end{aligned}
$$

where $R_{t}^{f}$ is the real risk-free interest rate.

\section{Final Goods Firm}

A final goods firm buys intermediate goods $Y_{i t}$ to produce final goods $Y_{t}$ to maximize profits. It takes intermediate goods prices $P_{i t}$ and final goods price $P_{t}$ as given. It produces $Y_{t}$ with CES technology

$$
Y_{t}=\left[\int_{0}^{1} Y_{i t}^{1-\frac{1}{\eta}} d i\right]^{\frac{1}{1-\frac{1}{\eta}}}
$$

Specifically, the final goods firm maximizes

$$
\begin{array}{ll}
\max _{Y_{i t}} & P_{t} Y_{t}-\int_{0}^{1} P_{i t} Y_{i t} d i \\
\text { s.t. } & Y_{t}=\left[\int_{0}^{1} Y_{i t}^{1-\frac{1}{\eta}} d i\right]^{\frac{1}{1-\frac{1}{\eta}}}
\end{array}
$$


The Lagrangian is

$$
\mathscr{L}=P_{t}\left[\int_{0}^{1} Y_{i t}^{1-\frac{1}{\eta}} d i\right]^{\frac{1}{1-\frac{1}{\eta}}}-\int_{0}^{1} P_{i t} Y_{i t} d i
$$

The FOC w.r.t. intermediate goods

$$
\begin{aligned}
\frac{\partial \mathscr{L}}{\partial Y_{i t}} & =P_{t}\left(\frac{Y_{t}}{Y_{i t}}\right)^{\frac{1}{\eta}}-P_{i t}=0 \\
Y_{i t} & =\left(\frac{P_{i t}}{P_{t}}\right)^{-\eta} Y_{t}
\end{aligned}
$$

The price index is

$$
\begin{aligned}
P_{t} Y_{t} & =\int_{0}^{1} P_{i t} Y_{i t} d i \\
& =\int_{0}^{1} P_{i t}\left(\frac{P_{i t}}{P_{t}}\right)^{-\eta} Y_{t} d i \\
P_{t} & =\left[\int_{0}^{1} P_{i t}^{1-\eta} d i\right]^{\frac{1}{1-\eta}}
\end{aligned}
$$

\section{Intermediate Goods Firms}

Monopolistically competitive firms choose labor $N_{i t}$ and price $P_{i t}$ and produce intermediate goods $Y_{i t}$ to maximize discounted real profits. Firms take wages as given and use constant return to scales production technologies

$$
\begin{aligned}
& F_{i t}=A_{t} N_{i t} \\
& F_{i t} \geq Y_{i t}
\end{aligned}
$$


Specifically firms maximize

$$
\begin{aligned}
\max _{\left\{N_{i t}, P_{i t}\right\}} & E_{t}\left[\sum_{j=0}^{\infty} M_{t, t+j}\left(\frac{P_{i, t+j} Y_{i, t+1}-W_{t+j} N_{i, t+j}}{P_{t+j}}\right)\right] \\
\text { s.t. } & Y_{i t}=A_{t} N_{i t} \\
& Y_{i t} \geq\left(\frac{P_{i t}}{P_{t}}\right)^{-\eta} Y_{t}
\end{aligned}
$$

The Lagrangian is

$$
\begin{aligned}
\mathscr{L} & =E_{t}\left[\sum_{j=0}^{\infty} M_{t, t+j}\left(\frac{P_{i, t+j} Y_{i, t+j}-W_{t} N_{i, t+j}}{P_{t+j}}\right)\right] \\
& +\cdots \\
& +\lambda_{1, t}\left(F_{i t}-Y_{i t}\right) \\
& +\lambda_{2, t}\left(Y_{i t}-\left(\frac{P_{i t}}{P_{t}}\right)^{-\eta} Y_{t}\right) \\
& +\cdots
\end{aligned}
$$

The FOC w.r.t. to labor is

$$
\begin{aligned}
\frac{\partial \mathscr{L}}{\partial N_{i t}} & =-\frac{W_{t}}{P_{t}}+\lambda_{1, t} F_{N, i t}=0 \\
\frac{W_{t}}{P_{t}} & =\lambda_{1, t} F_{N, i t}
\end{aligned}
$$

Note that $P_{t} \lambda_{1, t}=M C_{t}$ are the firms' nominal marginal costs. Firms' prices are assumed to be sticky à la Calvo. Each period, firms can update their price $P_{i t}$ with probability $1-\theta$. Firms choose the best price $P_{i t}$ at time $t$ knowing that they will not be able to reoptimize in the next period with probability $\theta$, i.e. they maximize

$$
\max _{P_{i t}} E_{t}\left[\sum_{j=0}^{\infty} \theta^{j} \frac{M_{t, t+j}}{P_{t+j}}\left(P_{i t} Y_{i, t+j}-W_{t+j} N_{i, t+j}\right)\right]
$$


Substituting in demand for labor and output, note that

$$
\begin{aligned}
P_{i t} Y_{i, t+j}-W_{t+j} N_{i, t+j} & =P_{i t} Y_{i, t+j}-M C_{t+j} Y_{i, t+j} \\
& =\left(P_{i t}-M C_{t+j}\right)\left(\frac{P_{i t}}{P_{t+j}}\right)^{-\eta} Y_{t+j} \\
& =\left(P_{i t}^{1-\eta}-M C_{t+j} P_{i t}^{-\eta}\right) P_{t+j}^{\eta} Y_{t+j}
\end{aligned}
$$

The Lagrangian is

$$
\mathscr{L}=E_{t}\left[\sum_{j=0}^{\infty} \theta^{j} M_{t, t+j}\left(P_{i t}^{1-\eta}-M C_{t+j} P_{i t}^{-\eta}\right) P_{t+j}^{\eta-1} Y_{t+j}\right]
$$

The FOC w.r.t. firm's price is

$$
\frac{\partial \mathscr{L}}{\partial P_{i t}}=E_{t}\left[\sum_{j=0}^{\infty} \theta^{j} M_{t, t+j}\left((1-\eta) P_{i t}^{-\eta}+\eta M C_{t} P_{i t}^{-\eta-1}\right) P_{t+j}^{\eta-1} Y_{t+j}\right]=0
$$

This implies

$$
\frac{P_{i t}}{P_{t}}=\frac{\eta}{\eta-1} \frac{E_{t}\left[\sum_{j=0}^{\infty} \theta^{j} M_{t, t+j}\left(\frac{P_{t+j}}{P_{t}}\right)^{\eta} Y_{t+j} m c_{t+j}\right]}{E_{t}\left[\sum_{j=0}^{\infty} \theta^{j} M_{t, t+j}\left(\frac{P_{t+j}}{P_{t}}\right)^{\eta-1} Y_{t+j}\right]}
$$

where $m c_{t}=\frac{M C_{t}}{P_{t}}$ are real marginal costs. The firm's price setting equation can be written recurrsively as

$$
\begin{aligned}
P_{t}^{*} & =\frac{\eta}{\eta-1} \frac{\zeta_{t}}{\xi_{t}} \\
\zeta_{t} & =m c_{t} \cdot Y_{t}+\theta E_{t}\left[M_{t+1} \Pi_{t+1}^{\eta} \zeta_{t+1}\right] \\
\xi_{t} & =Y_{t}+\theta E_{t}\left[M_{t+1} \Pi_{t+1}^{\eta-1} \xi_{t+1}\right]
\end{aligned}
$$

where $P_{t}^{*}=\frac{P_{i t}}{P_{t}}$. 


\section{Government}

Monetary policy follows a Taylor (1993) rule

$$
\begin{aligned}
\frac{I_{t}^{f}}{I} & =\left(\frac{I_{t-1}^{f}}{I}\right)^{\rho_{I}}\left[\left(\frac{Y_{t}}{\bar{Y}_{t}}\right)^{\beta_{Y}}\left(\frac{\Pi_{t}}{\Pi}\right)^{\beta_{\pi}}\left(\frac{P_{t}}{\bar{P}_{t}}\right)^{\beta_{P}}\right]^{1-\rho_{I}} e^{\varepsilon_{i, t}} \\
\frac{Y_{t}}{\bar{Y}_{t}} & =\frac{\Delta Y_{t}}{\Delta Y} \frac{Y_{t-1}}{\bar{Y}_{t-1}} \\
\frac{P_{t}}{\bar{P}_{t}} & =\frac{\Pi_{t}}{\bar{\Pi}_{t}} \frac{P_{t-1}}{\bar{P}_{t-1}} \\
\bar{\Pi}_{t} & =\prod e^{x_{\pi, t}} \\
x_{\pi, t} & =\rho_{\pi} x_{\pi, t}+\varepsilon_{\pi, t}
\end{aligned}
$$

where $\varepsilon_{i, t}$ and $\varepsilon_{\pi, t}$ are monetary policy and inflation target shocks.

\section{Equilibrium}

The aggregate resource constraint

$$
\begin{aligned}
& Y_{t}=C_{t} \\
& Y_{t}=\frac{F_{t}}{S_{t}}
\end{aligned}
$$

where price dispersion is

$$
S_{t}=(1-\theta) P_{t}^{*-\eta}+\theta \Pi_{t}^{\eta} S_{t-1}
$$

Prices follow

$$
1=(1-\theta) P_{t}^{* 1-\eta}+\theta \Pi_{t}^{\eta-1}
$$




\section{Technology}

Technology evolves according to

$$
\begin{aligned}
\Delta a_{t+1} & =\mu+x_{t}+\varepsilon_{a, t+1} \\
x_{t+1} & =\rho x_{t}+\varepsilon_{x, t+1}
\end{aligned}
$$




\section{REFERENCES}

Adam, K. and R. M. Billi (2006). Optimal Monetary Policy Under Commitment with a Zero Bound on Nominal Interest Rates. Journal of Money, Credit, and Banking 38(7), 1877-1905.

Bansal, R., D. Kiku, and A. Yaron (2012). An empirical evaluation of the long-run risks model for asset prices. Critical Finance Review 1(2), 183-221.

Bansal, R. and I. Shaliastovich (2013, nov). A Long-Run Risks Explanation of Predictability Puzzles in Bond and Currency Markets. Review of Financial Studies 26(1), 1-33.

Bansal, R. and A. Yaron (2004). Risks for the Long Run: A Potential Resolution of Asset Pricing Puzzles. Journal of Finance 59(4), 1481-1509.

Basu, S. and B. Bundick (2015). Endogenous Volatility at the Zero Lower Bound : Implications for Stabilization Policy. Working Paper.

Bekaert, G., S. Cho, and A. Moreno (2010, nov). New Keynesian Macroeconomics and the Term Structure. Journal of Money, Credit and Banking 42(1), 33-62.

Black, F. (1995, nov). Interest Rates as Options. The Journal of Finance 50(5), 1371-1376.

Calvo, G. A. (1983). Staggered prices in a utility-maximizing framework. Journal of monetary Economics 12(3), 383-398.

Campbell, J., C. Pflueger, and L. M. Viceira (2015). Monetary policy drivers of bond and equity risks. Working Paper.

Campbell, J., R. Shiller, and L. Viceira (2009). Understanding inflation-indexed bond markets. Technical report.

Campbell, J., A. Sunderam, and L. M. Viceira (2013). Inflation bets or deflation hedges? The changing risks of nominal bonds. Technical report.

Clarida, R., J. Galí, and M. Gertler (1999). The Science of Monetary Policy: A New Keynesian Perspective. Journal of Economic Literature 37(4), 1661-1707.

Colacito, R., E. Ghysels, J. Meng, and W. Siwasarit (2016). Skewness in Expected Macro Fundamentals and the Predictability of Equity Returns: Evidence and Theory. The Review of Financial Studies.

Coleman, J. (1990, nov). Solving the Stochastic Growth Model by Policy-Function Iteration. Journal of Business \& Economic Statistics 8(1), 27-29.

Croce, M. (2014, nov). Long-run productivity risk: A new hope for production-based asset pricing? Journal of Monetary Economics 66, 13-31. 
Epstein, L. G. and S. E. Zin (1989). Substitution, risk aversion, and the temporal behavior of consumption and asset returns: A theoretical framework. Econometrica: Journal of the Econometric Society, 937-969.

Fernald, J. (2014). Productivity and Potential Output Before, During, and After the Great Recession. Technical report.

Fernández-Villaverde, J., G. Gordon, P. Guerrón-Quintana, and J. Rubio-Ramírez (2015, nov). Nonlinear adventures at the zero lower bound. Journal of Economic Dynamics and Control 57(12), 182-204.

Kim, D. H. and K. Singleton (2012, nov). Term structure models and the zero bound: an empirical investigation of Japanese yields. Journal of Econometrics 170(1), 32-49.

Krugman, P. (1998). It's baaack: Japan's slump and the return of the liquidity trap. Brookings Papers on Economic Activity 1998(2), 137-205.

Kung, H. (2015, nov). Macroeconomic linkages between monetary policy and the term structure of interest rates. Journal of Financial Economics 115(1), 42-57.

Li, E. X. and F. Palomino (2014). Nominal rigidities, asset returns, and monetary policy. Journal of Monetary Economics 66, 210-225.

Nakata, T. (2012). Uncertainty at the Zero Lower Bound. pp. 1-37.

Ohanian, L. E. and A. Raffo (2012). Aggregate hours worked in OECD countries: New measurement and implications for business cycles. Journal of Monetary Economics 59(1), 40-56.

Pflueger, C. and L. M. Viceira (2016). Return Predictability in the Treasury Market: Real rates, Inflation, and Liquidity. In Handbook of Fixed-Income Securities, Chapter 10. Wiley.

Piazzesi, M. and M. Schneider (2007). Equilibrium yield curves. In NBER Macroeconomics Annual 2006, Volume 21, Volume 21, pp. 389-472. MIT Press.

Rudebusch, G. D. and T. Wu (2008). A macro-finance model of the term structure, monetary policy and the economy. Economic Journal 118(530), 906-926.

Schmitt-Grohé, S. and M. Uribe (2007, nov). Optimal simple and implementable monetary and fiscal rules. Journal of Monetary Economics 54(6), 1702-1725.

Swanson, E. and G. D. Rudebusch (2012). The Bond Premium in a DSGE Model with Long-Run Real and Nominal Risks. American Economic Journal: Macroeconomics 4(1), 1-5.

Swanson, E. and J. C. Williams (2014). Measuring the effect of the zero lower bound on mediumand longer-term interest rates. American Economic Review 104(10), 3154-3185.

Taylor, J. B. (1993). Discretion versus policy rules in practice. In Carnegie-Rochester conference 
series on public policy, Volume 39, pp. 195-214. Elsevier. 